\title{
Early Middle Devonian trilobites and events in the Nismes - Vireux-Molhain area, southern border of the Dinant Synclinorium (Belgium, northern France)
}

\author{
Allart P. VAN VIERSEN ${ }^{1 *}$, Peter TAGHON ${ }^{2} \&$ Benedikt MAGREAN $^{3}$
}

\author{
1. Natuurhistorisch Museum Maastricht, De Bosquetplein 6-7, 6211 KJ Maastricht, The Netherlands; apvanviersen@gmail.com. \\ 2. Deinse Horsweg 12,9031 Gent, Belgium; peter.taghon@telenet.be. \\ 3.Neustraße 7,52159 Roetgen, Germany; ben@magrean.de. \\ *corresponding author.
}

\begin{abstract}
Well-preserved trilobite specimens are recorded from Eifelian strata between the villages of Nismes (southern Belgium) and Vireux-Molhain (northern France). In the area of study the lower Eifelian Vieux Moulin Member of the Jemelle Formation crops out. The diversified trilobite associations of this unit occur in dark shales and siltstones during a deepening phase and replace the comparatively poorly diversified trilobite fauna of the underlying Eau Noire Formation. This overturn of the local trilobite fauna might, in part, be considered a regional expression of the globally recognised Choteč Event. A marked influx of exotic trilobites in the Vieux Moulin Member is provisionally referred to the local Vieux Moulin Event. Trilobite diversity peaked in the middle Eifelian part (Chavées Member) of the Jemelle Formation before drastically dropping in the upper part of this formation. The manifestations in the Ardennes of the eastern North American Bakoven and Stony Hollow Events can neither be confirmed nor rejected based on the currently available data. New taxa from the early Eifelian part of the Jemelle Formation in the area of study are Asteropyge boeckae sp. nov., Asteropyge eonia sp. nov., Asteropyge filoxenia sp. nov., Cyphaspis insolata sp. nov., Cyphaspis iuxta sp. nov., Diademaproetus pertinax sp. nov., Geesops icovellaunae sp. nov., Gerastos kesselaeri sp. nov., Kettneraspis eftychia sp. nov., Pedinopariops ceuthonymus sp. nov., Pedinopariops richterianus geminus ssp. nov., Scabriscutellum archinalae sp. nov., Septimopeltis akatastasia sp. nov. and Tropidocoryphe insciens sp. nov. Our material includes exceptionally rare, well-preserved specimens from the famous "Mur des douaniers" locality near VireuxMolhain. Additionally, Astycoryphe rugocauda sp. nov. is described from the lower Eifelian Couvin Formation (southern Belgium) and Gerastos silvicultrix sp. nov. from the uppermost Emsian Heisdorf Formation (German Eifel).
\end{abstract}

KEYWORDS: Trilobites, systematic palaeontology, palaeobiogeography, events.

\section{Introduction}

The Eifelian rocks that crop out in southern Belgium and northern France (Fig. 1) have long been known for their highly diversified trilobite assemblages (e.g. Gosselet, 1884; Maillieux, 1904, 1907a, 1919, 1933, 1938; Richter, 1914; Lecompte, 1962). Records in the old literature chiefly encompass lists of outdated trilobite names. These are typically grouped according to obsolete stratigraphic divisions and come without references to the specimens. The only published accounts to contain useful descriptions and illustrations are those of Maillieux (1904, 1907b, 1938). After decades of little to no trilobite research in Belgium, Struve (1982b, 1985) described several phacopids from Eifelian strata between Couvin and Vireux-Molhain. Since then, a number of papers have dealt with Eifelian trilobites in the area (e.g. Magrean, 2007; Taghon et al., 2012; van Viersen, 2015, and references therein).

During field excursions over the past years in southern Belgium the authors of the present paper noticed that the early Eifelian trilobite fauna shows marked differences from that of the upper Emsian. Genera such as Acastoides and Basidechenella do not cross the Eifelian boundary. This loss is more than fully compensated by the introduction of genera not known from older strata in the region. This work is the first part in a series of descriptions of early Eifelian trilobites from the Jemelle Formation in southern Belgium and northern France.

\section{Geological context}

\subsection{Lithostratigraphy}

Along the southern limb of the Dinant Synclinorium the EmsianEifelian boundary is situated within the upper part of the Eau Noire Formation, $50 \mathrm{~m}$ above the base of this unit in Couvin (Fig. 2; Bultynck et al., 1991). The Eau Noire Formation encompasses an alternation of argillaceous to crinoidal limestone beds and calcareous shales with bioclasts. It is surmounted by the lower to upper Eifelian Jemelle Formation which, in its stratotype at Jemelle, encompasses (from bottom to top): the Station Member (sandy shales), the Cimetière Member (shales with nodular or lenticular limestones), and the Chavées Member (alternation of shales and limestone beds) (Godefroid, 1968; Bultynck et al., 1991; Bultynck \& Dejonghe, 2001). Small bioherms are developed in the upper part of the Jemelle Formation (Lecompte, 1970; Bultynck et al., 1991). This configuration is different in the

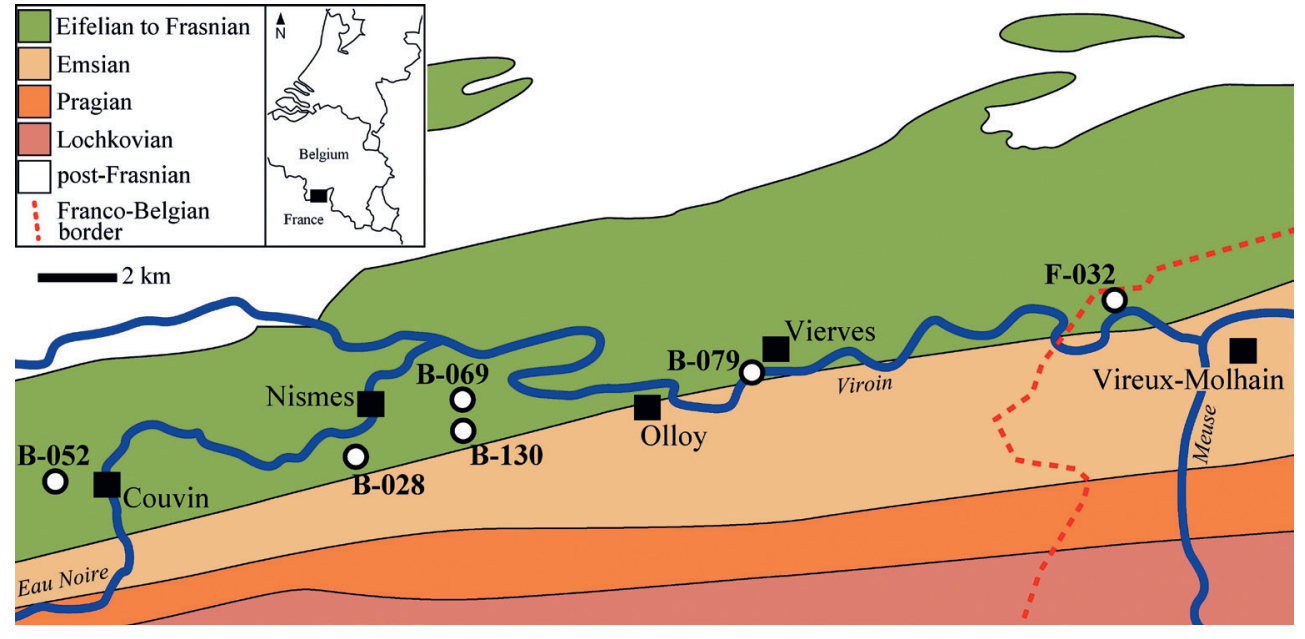

Figure 1. Geological map of the Nismes - Vireux-Molhain area (Belgium, northern France) with trilobite-bearing localities indicated. Modified after de Béthune (1954). 


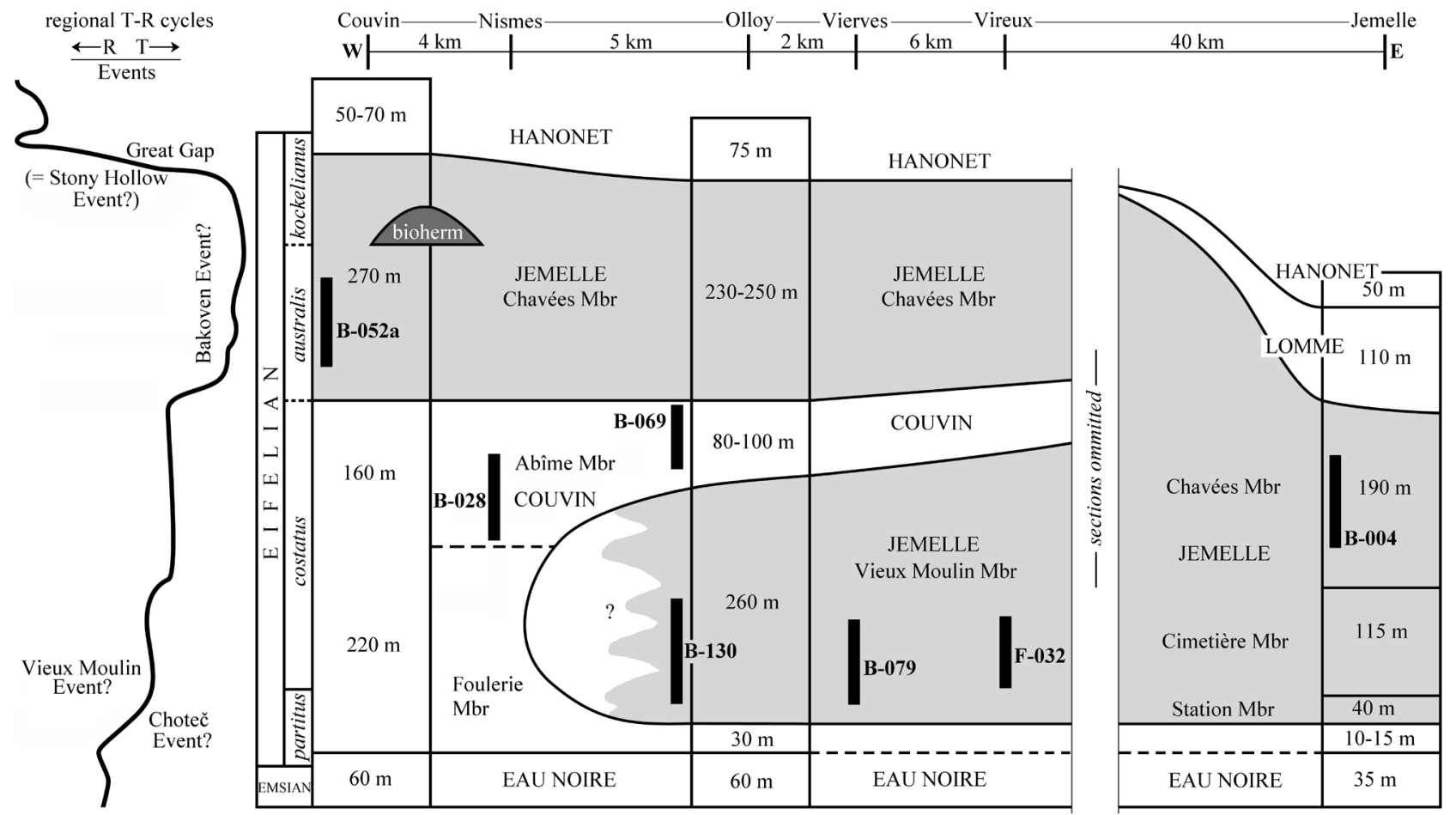

Figure 2. Uppermost Emsian to Eifelian stratigraphy on the southern limb of the Dinant Synclinorium with the maximum ranges of trilobite-bearing sections indicated (adopted from Dumoulin \& Blockmans, 2008 and modified). T-R curve adopted from Gouwy \& Bultynck (2003). The Bakoven Event, positioned as according to Denayer et al. (2015); considered uncertain in the present note. Geographic distances between sections in km.

Couvin area where only the upper Chavées Member is developed. The lower part of the Jemelle Formation is replaced here by the Couvin Formation (Bultynck, 1970; Bultynck et al., 1991; Bultynck \& Dejonghe, 2001). The latter consists of limestones with biostromes; it is well-developed near Couvin and drastically reduced in thickness east of Nismes where only its upper part persists. Underneath, the shales and siltstones of the Jemelle Formation occur but Dumoulin \& Blockmans (2008) considered these levels to be incompatible with the lower Station and Cimetière members in the stratotype. Dumoulin \& Blockmans assigned them to the new Vieux Moulin Member instead with at the base, a level of homogeneous dark, finely bioclastic (crinoids, trilobites, etc.) shales, and at the top, thick beds of siltstones, sometimes laminar, and sometimes containing accumulations of fossils near the bases of some beds.

\subsection{Localities}

F-032 'Mur des douaniers' locality, Vireux-Molhain (northern France); Vieux Moulin Member of the Jemelle Formation, early Eifelian (Crônier \& van Viersen, 2008; Dumoulin \& Blockmans, 2008).

This locality is a famous rock outcrop along the route D47 connecting Treignes and Vireux-Molhain. The earliest reports of abundant phacopid trilobites in this area date from the late 19th century (van Viersen \& Daumeries, 2012), as a result of exploration of shales originating from construction works of the nearby Najauge railway tunnel. For many decades the 'Mur des douaniers' was frequented by collectors for its rich trilobite fauna although the specimens are decalcified and severely tectonically distorted, almost without exception. The site was declared a natural reserve by French authorities in 1991. According to a panel that was placed there, the outcropping rocks belong to the St. Joseph Formation (Emsian). Van Viersen (2006a) assigned these to the basal part of the overlying Jemelle Formation instead, based on the occurrence of the goniatite Pinacites jugleri (see Schraut, 2000) and the typically Eifelian trilobite association.

The poor preservation of the trilobite material from this locality has greatly hindered taxonomic studies. Maillieux (1938) was the first to formally establish a new trilobite species in describing Septimopeltis magnispina. Additionally, Geesops gallicus Struve, 1982b, Gerastos catervus (van Viersen, 2006a) and Ceratarges cognatus van Viersen, 2006a have been described, as well as species of Cyphaspis, Pedinopariops, Diademaproetus?, Kettneraspis, Koneprusia, Scabriscutellum and an undetermined genus of Asteropyginae. The most comprehensive account of the trilobites from F-032 to date is that of van Viersen \& Daumeries (2012). In the present paper, we record rare specimens of unprecedented quality that have the calcareous cuticle preserved, as well as several detailed external moulds, all of which come from old collections. These are referred to Asteropyge eonia sp. nov., Cyphaspis cf. iuxta sp. nov., Diademaproetus cf. pertinax sp. nov., Geesops gallicus, Gerastos catervus, Kettneraspis eftychia sp. nov., Koneprusia sp. A and Pedinopariops ceuthonymus sp. nov.

A noteworthy aspect of the F-032 locality is the wealth of complete trilobite specimens that it has yielded. One of us (AV) has examined several thousands of trilobites in private and museum collections, the vast majority of which are fully articulated. These numbers are exceptional for any locality in the Ardenno-Rhenish Mountains. Of note is that nearby coeval strata just across the Belgian border have yielded the same trilobite species but the specimens are scarce, poorly preserved isolated sclerites (van Viersen \& Daumeries, 2012). The abundance of complete trilobites at the 'Mur des douaniers' remains largely unexplored since new excavations for scientific studies there are not permitted (Crônier \& van Viersen, 2008; van Viersen, 2008). Some clues are nonetheless provided by the trilobites. From a taphonomic point of view the large quantities of complete trilobites, which were prone to postmortal disarticulation, are suggestive of deposition below fair weather wave base. This is in line with the observations of fine laminae of very distal storms slightly above (Dumoulin in Crônier \& van Viersen, 2008). Van Viersen (2006a), who examined sizable rocks in private collections, reported mass occurrences of Gerastos catervus, articulated and in various orientations, in several $\mathrm{cm}$ thick banks. A geological context is lacking for such samples but based on current knowledge, we speculate that the most parsimonious explanation would be to regard these as obrution deposits.

B-004, Jemelle (Belgium); Chavées Member of the Jemelle Formation, middle Eifelian (Maillieux, 1938; van Viersen \& Prescher, 2008). 
Embankment near the Jemelle railway station. Van Viersen \& Prescher (2008) provided a complete list of trilobite species. These include members of Asteropyge, Astycoryphe, Ceratarges, Cornuproetus, Cyphaspis (several species), Dohmiella, Eifliarges, Geesops, Gerastos (several species), Goldius (several species), Harpes, Kettneraspis, Koneprusia, Pedinopariops (several species), Phacops, Radiaspis, Scabriscutellum and Tropidocoryphe.

B-028, Nismes (Belgium); upper part of the Couvin Formation, early Eifelian.

Abandoned quarry south of Nismes. This locality and its trilobites were described by van Viersen (2006b), van Viersen \& Prescher (2007) and van Viersen \& de Wilde (2010), who assigned the outcrop to the Foulerie Member of the Couvin Formation. However, it has become evident that these levels should be assigned to the Abîme Member instead (J. Denayer, pers. comm., December 2018). Trilobite specimens are often found disarticulated and accumulated. Complete specimens show putative signs of some transportation (van Viersen $\&$ de Wilde, 2010). Species include Astycoryphe rugocauda sp. nov., Ceratarges cf. cognatus van Viersen, 2006, Cyphaspis belgica van Viersen \& Prescher, 2007, Dohmiella dewildei van Viersen, 2006, Goldius angusticalix van Viersen \& de Wilde, 2010, Phacops sp., Scabriscutellum sp. A of van Viersen \& de Wilde (2010) and Tropidocoryphe sp.

B-052, Couvin (Belgium); Chavées Member of the Jemelle Formation, middle Eifelian (Maillieux, 1938).

Agricultural field west of Couvin indicated as locality 'Couvin $8011^{\prime}$ on Maillieux's field maps which are kept by the IRSNB. Trilobites were described by van Viersen (2015) and van Viersen et al. (2017a). These include members of Austerops, Ceratarges, Cornuproetus, Cyphaspis (multiple species), Dohmiella, Gerastos (multiple species), Goldius, Harpes, Kettneraspis, Koneprusia, Pedinopariops, Phacops, Phaetonellus, Scabriscutellum and Tropidocoryphe.

B-069, Olloy-sur-Viroin (Belgium); summit of the Couvin Formation, early Eifelian.

Agricultural field west of Olloy. Trilobites belonging to Cyphaspis and Dohmiella occur in crinoidal limestones.

B-079, Vierves-sur-Viroin (Belgium); Vieux Moulin Member of the Jemelle Formation, early Eifelian.

The Vierves locality was already known in the 1930 s by Maillieux (J. Denayer, pers. comm. in December 2018) although we were unable to find it on the field maps kept by the IRSNB that we have studied. The site was rediscovered by Tim Suffeleers during prospection in the area in 2015. Trilobites were recovered from dark shales and siltstones basally in the Vieux Moulin Member. Goniatites identified as Pinacites jugleri have also been recovered and will be described elsewhere (Goolaerts et al., in preparation). We speculate that the regular occurrences of partially and fully articulated trilobite specimens are suggestive of deposition close to fair weather wave base. Although complete trilobites are fairly common, clustered occurrences have not been observed. Taxa described are Asteropyge boeckae sp. nov., Cyphaspis iuxta sp. nov., Diademaproetus pertinax sp. nov., Gerastos catervus and Tropidocoryphe insciens sp. nov. Besides the trilobites described herein, other species of Ceratarges, Cyphaspis, Gerastos, Kettneraspis, Radiaspis, Septimopeltis and Phacopidae were discovered. These will be described in a future paper.

B-130, Nismes (Belgium); Vieux Moulin Member of the Jemelle Formation, early Eifelian.

Outcrop in the lower part of the Vieux Moulin Member just east of Nismes, indicated on Maillieux's field maps as 'Olloy 7971' and visited by two of us (PT, BM) in 2009. This site is comparable to B-079, Vierves, in terms of its age and trilobite fauna. Among the identified taxa are Asteropyge filoxenia sp. nov., Cyphaspis insolata sp. nov., Cyphaspis iuxta sp. nov., Diademaproetus pertinax sp. nov., Geesops cf. icovellaunae sp. nov., Gerastos catervus, Gerastos kesselaeri sp. nov., Pedinopariops richterianus geminus ssp. nov., Scabriscutellum archinalae sp. nov., Septimopeltis akatastasia sp. nov. and Tropidocoryphe insciens sp. nov.

G-099, Ahütte (Germany); Heisdorf Formation, uppermost Emsian (Fig. 20).

Outcrop in the forestal area $1300 \mathrm{mNNE}$ of the centre of Ahütte, Eifel, visited by one of us (AV) with the late Harald Prescher in 2007. Trilobites were recovered from crinoidal limestones high in the Heisdorf Formation. The association is poorly diversified and encompasses Acastoides sp., Basidechenella kayseri (Richter, 1909) and Gerastos silvicultrix sp. nov.

Though not directly related to the main topic of this study, we describe Gerastos silvicultrix as a member of a genus that settled in the Ardenno-Rhenish Mountains during the studied stratigraphic interval. An exceedingly similar cranidium from the St. Joseph Formation which underlies the Eau Noire Formation in southern Belgium, was illustrated by van Viersen (2015, p. 16, fig. 34).

\section{Systematic palaeontology}

All the figured specimens were whitened with ammonium chloride prior to photography. The type material is housed by the Institut royal des Sciences naturelles de Belgique (IRSNB), the Geo-Instituut of the Katholieke Universiteit Leuven (PLI) and the Natuurhistorisch Museum Maastricht (NHMM). Morphologic terminology follows that of the Revised Trilobite Treatise (Whittington \& Kelly, 1997). The terms fixigenal tubercle 'Fx4', 'subocular patch' and 'posterior tegimen' were adopted from van Viersen \& Holland (2016, p. 254). The term 'anterior ledge' is used for the elongated (sag.) anterior border in certain taxa.

Family Acastidae Delo, 1935

Subfamily Asteropyginae Delo, 1935

\section{Genus Asteropyge Hawle \& Corda, 1847}

Type species. Olenus punctatus Steininger, 1831.

Discussion. Known species diversity of this genus has grown considerably over the past decades despite its restricted concept (see Basse, 2003). With the exception of Asteropyge perforata Morzadec, 1969 from the upper Emsian in Brittany and lower Eifelian in Spain, all taxa come from the Ardenno-Rhenish Mountains. The majority of these are of early Eifelian age. Members of Asteropyge are adapted to siliciclastic sediments, occurring typically in sandy shales and siltstones. In Belgium they have never been discovered in the carbonate environments such as the Couvin Formation or the bioherms of the Jemelle Formation.

\section{Asteropyge boeckae sp. nov.}

(Fig. 3)

Etymology. Named after Joke De Boeck, spouse of Tim Suffeleers.

\section{Holotype. IRSNB a13272, complete specimen.}

Type locality and horizon. B-079, Vierves; Vieux Moulin Member of the Jemelle Formation.

Diagnosis. Glabella covered with densely spaced, large tubercles centrally; these become smaller and more widely spaced anteriorly and laterally. Broad anterior ledge with small tubercles on outer half. Visual surface containing 26?/7 lenses. Palpebral lobe bearing few large tubercles near outer edge. Librigenal field bearing small, closely spaced tubercles. Genal spine long, straight, and slightly tapered; only distally clearly reduced in 


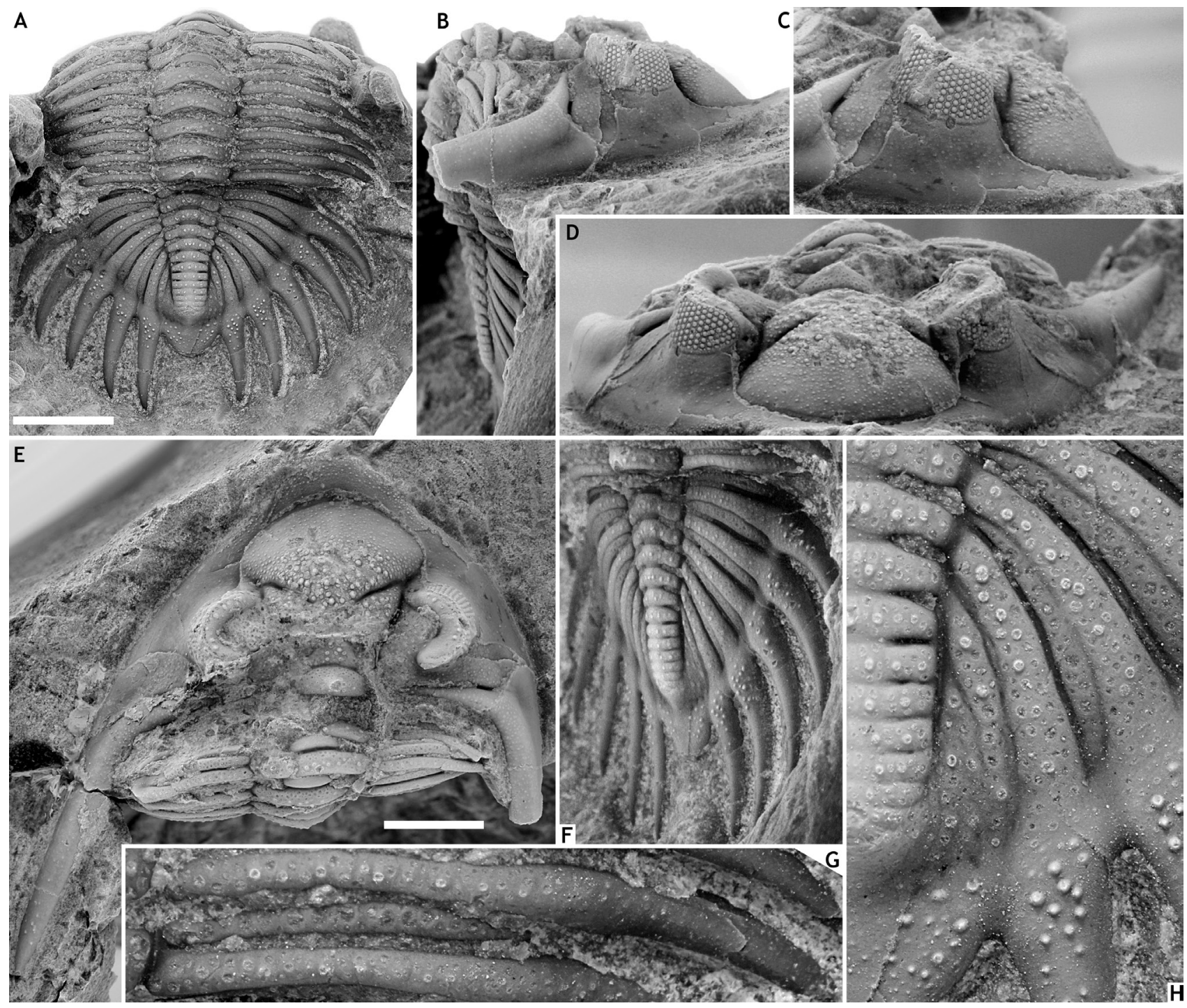

Figure 3. Asteropyge boeckae sp. nov. from the Vieux Moulin Member of the Jemelle Formation at B-079, Vierves. Holotype complete specimen, IRSNB a13272, in dorsal view of pygidium (A), lateral (B), oblique lateral (C), oblique anterior (D), dorsal view of cephalon (E), oblique lateral view of pygidium $(\mathrm{F})$, close-up of thoracic pleurae $(\mathrm{G})$ and close-up of pygidium $(\mathrm{H})$.

All scale bars represent $5 \mathrm{~mm}$.

thickness and acuminate. Thorax with "pores" on anterior pleural bands and anterior half of axial rings; posterior pleural bands and posterior half of axial rings bearing a single row of tubercles. Pygidial axis consisting of 13 rings plus terminal piece; bearing randomly scattered "pores"; two to three axial-symmetric pairs of tubercles on each ring and a median tubercle on some rings. Anterior five inter-ring furrows deepest and rings posteriorly arched here; posterior inter-ring furrows medially shallow to absent and rings straight (tr.) here. Six pairs of pygidial pleurae with sculpture similar to that on the thoracic pleurae. Acuminate, sword-shaped pygidial pleural spines with comparatively few tubercles crowded on their bases. Subsemicircular median lappet bearing large tubercles abaxially and few, small tubercles medially.

Discussion. Asteropyge boeckae sp. nov. differs from Asteropyge filoxenia sp. nov. (Fig. 4) as expressed in their respective diagnoses. These species are easily discriminated by their different sculpture, the presence of an anterior ledge and the shape of the pygidial median lappet. Asteropyge eonia sp. nov. (Fig. 5) has a short anterior ledge and generally very different sculpture consisting mainly of tubercles.

Asteropyge plana Basse, 2003 was described on the basis of a pygidium from the Lauch Formation (lower Eifelian) in the Eifel. It is different from $A$. boeckae sp. nov. in having 12 axial rings with "pores" laterally and tubercles medially, shallow inter- ring furrows (especially anterior five), shallow axial furrows (especially near ring 7 and backward), five pairs of pleurae, and narrower bases of pleural spines (as far as these spines are preserved in A. plana).

\section{Asteropyge filoxenia sp. nov.}

(Fig. 4)

Etymology. From $\varphi \imath \lambda \mathrm{o} \xi \varepsilon v i ́ \alpha$ (Greek; a friend to strangers).

Holotype. IRSNB a13273, articulated specimen (Figs 4E-H).

Paratype. NHMM 2018058 (Figs 4A-D), cephalon with attached thoracic tergites, from type locality and horizon.

Type locality and horizon. B-130, Nismes; Vieux Moulin Member of the Jemelle Formation.

Diagnosis. Glabella bearing comparatively few, randomly scattered tubercles centrally. Rest of glabella, palpebral area and librigenal field bearing "pores" of varying sizes. Visual surface containing 27/9 lenses. Large, robust genal spines with a furrow restricted to its base; covered with numerous tubercles that are of reduced size abaxially. Thorax covered with "pores" which become smaller distally until absent on the tips. Pygidial axis and pleural field covered with "pores"; a few tubercles visible 

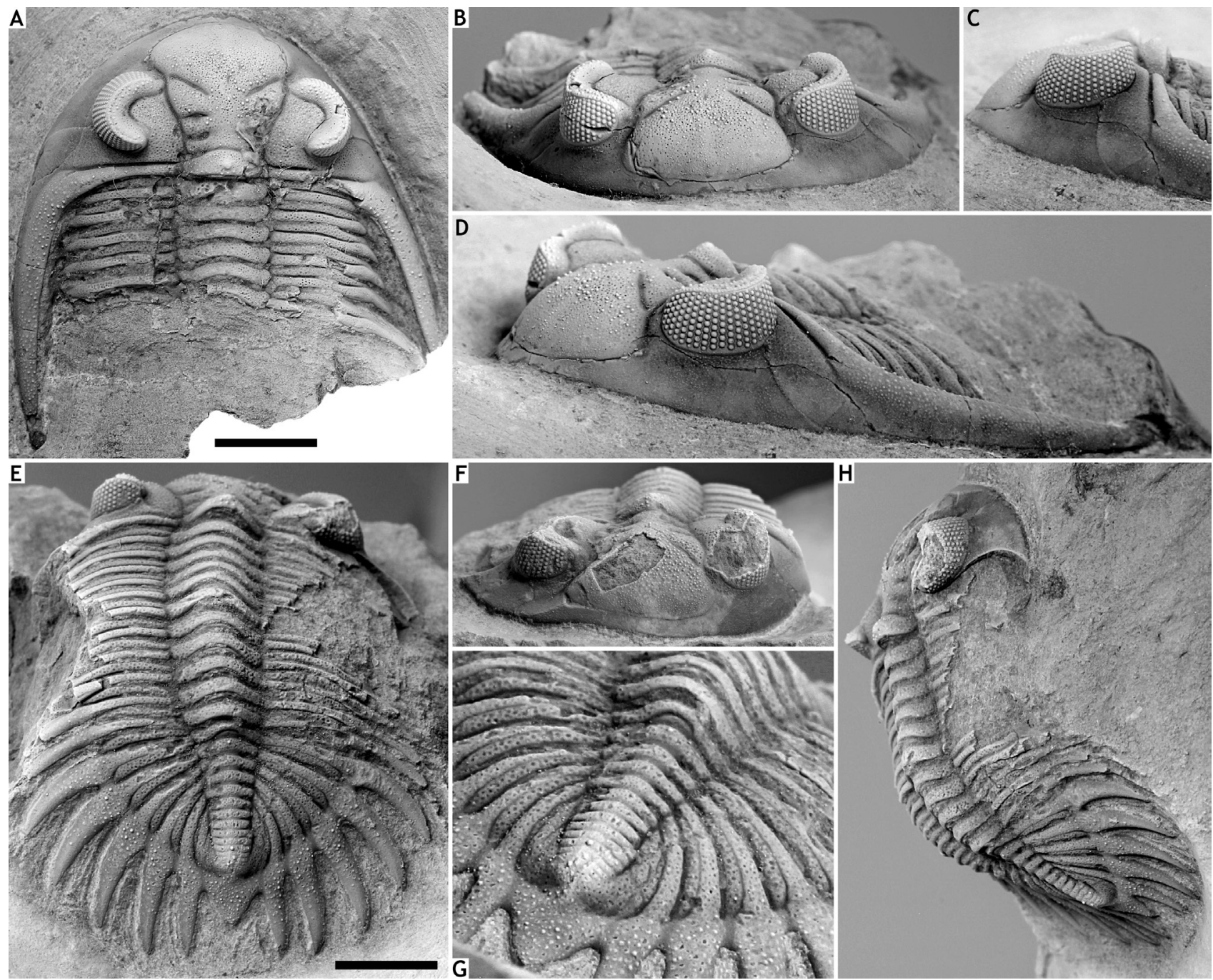

Figure 4. Asteropyge filoxenia sp. nov. from the Vieux Moulin Member of the Jemelle Formation at B-130, Nismes.

A-D. Paratype cephalon with attached thoracic tergites, NHMM 2018 058, in dorsal (A), anterior (B), lateral (C) and anterolateral (D) views.

E-H. Holotype articulated specimen, IRSNB a13273, in dorsal view of pygidium (E), anterior (F), oblique posterolateral (G) and oblique lateral (H) views.

All scale bars represent $5 \mathrm{~mm}$.

medially on axis. Six pairs of pygidial pleurae. Broad, swordshaped pygidial pleural spines with densely spaced tubercles restricted to proximal half. Pleural spines hardly longer than associated pleurae.

Discussion. This species bears similarities to Asteropyge pruemensis Basse, 2003 from the basal part of the Nohn Formation (lower Eifelian) in the Eifel, in that both species have a widely parabolic cephalic outline without an anterior ledge, small pits on the pygidial pleurae (no tubercles), sword-shaped pygidial pleural spines, and an elongated subtriangular pygidial median lappet. Asteropyge filoxenia sp. nov. is contrasted by its distally shallow S2 and S3, larger eyes (merely 24/4-6 in $A$. pruemensis), much larger genal spines without a distinct furrow, distally widened posterior pleural bands where they run onto the pygidial border, broader, shorter pygidial pleural spines distally devoid of tubercles, and a broader pygidial border.

\section{Asteropyge eonia sp. nov.}

(Fig. 5)

2016 Greenops oder Stummiana sp.; Basse \& Müller, pl. 31, fig. 316.

Etymology. Derived from aıóvı (Greek; eternity).

Holotype. IRSNB a13274, complete specimen (Figs 5A, E-J).
Paratypes. NHMM 201856 (Figs 5B, D, K-N), NHMM 2018 057 (Fig. 5C), two complete specimens, from type locality and horizon.

Type locality and horizon. F-032, Vireux-Molhain; Vieux Moulin Member of the Jemelle Formation.

Diagnosis. High parabolic to slightly subtriangular cephalic outline. Weakly vaulted border anterior to glabella bearing fine tubercles. Short anterior ledge. Occipital ring bearing tubercles centrally but without a median tubercle. Glabella bearing numerous small tubercles that are slightly larger centrally. Straight, robust, dorsoventrally high genal spines of equal width (tr.) throughout; dorsally and abaxially covered with densely spaced tubercles; with outward pointed spiny tip. Pygidial axis bearing large tubercles centrally. Pygidial pleural field, border, spines and median lappet entirely covered with tubercles.

Discussion. Van Viersen (2008) commented on the often very poor preservation of members of the Asteropyginae from F-032, making it difficult to identify them even at the genus level. According to Gibout in van Viersen \& Daumeries (2012), asteropygines occur in sandy beds at the base and near the top of the 'Mur des douaniers' section. Clearly, taphonomy in these levels has been unfavourable to the trilobite specimens. The asteropygines have been variably listed as Asteropyge punctata and potential Asteropyge, Kayserops, Stummiana or Greenops 


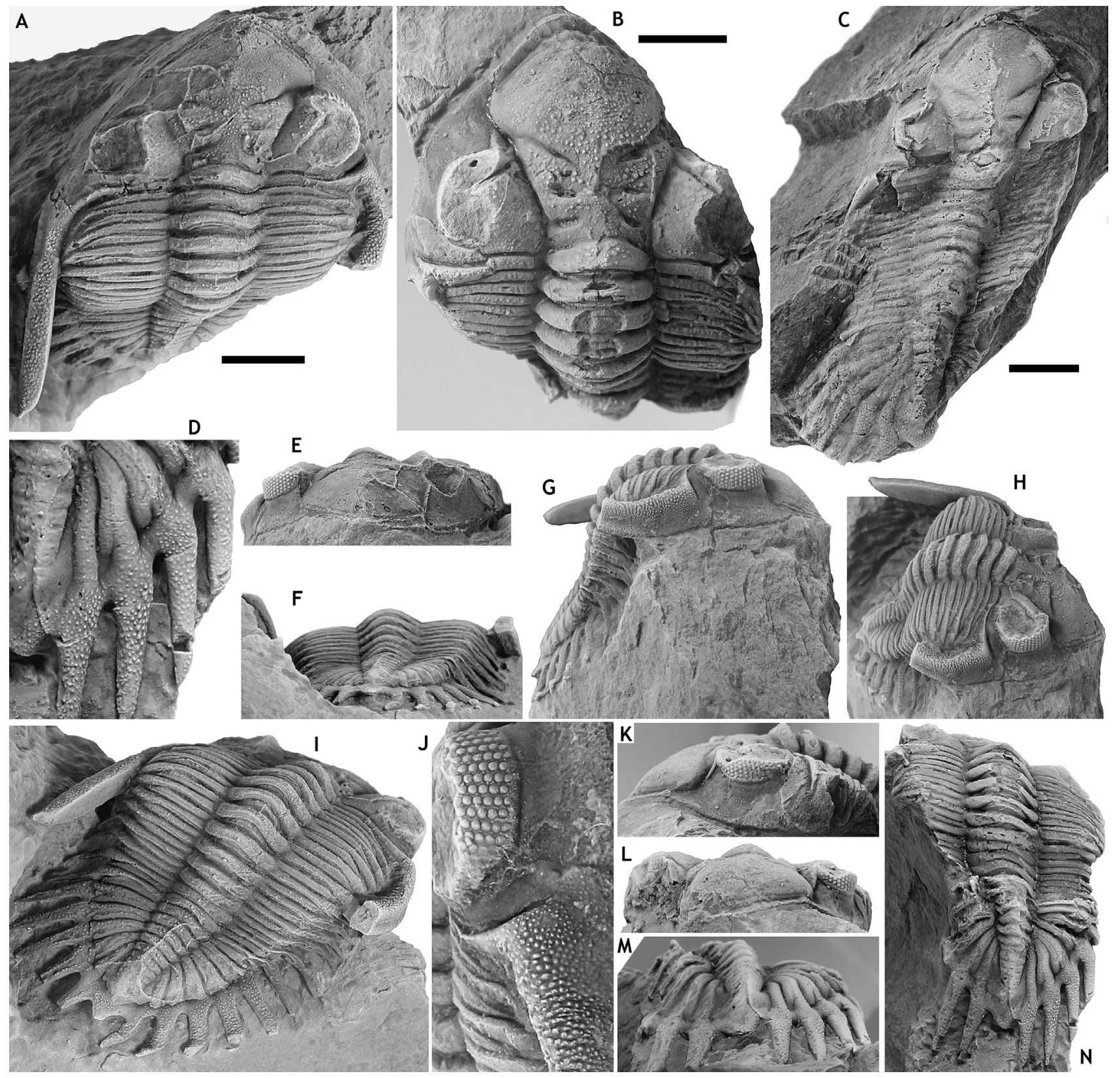

Figure 5. Asteropyge eonia sp. nov. from the Vieux Moulin Member of the Jemelle Formation at F-032, Vireux-Molhain. All specimens have the cuticle preserved.

A, E-J. Holotype complete specimen, IRSNB a13274, in dorsal view of cephalon (A), anterior (E), posterior (F), lateral (G), oblique lateral (H) views, dorsal view of pygidium (I) and close-up of right eye (J).

B, D, K-N. Paratype complete specimen, NHMM 2018 056, in dorsal view of cephalon (B), close-up of pygidium (D), lateral (K), anterior (L) and posterior $(\mathrm{M})$ views, and dorsal view of pygidium $(\mathrm{N})$.

C. Paratype complete specimen, NHMM 2018 057, in dorsal view.

All scale bars represent $5 \mathrm{~mm}$.

species, and as undetermined members of Asteropyginae. It is pointless to attempt a comparison of these records with our comparatively well-preserved material. Only Basse \& Müller's (2016) specimen from F-032 is similar to ours and potentially conspecific.

Asteropyge eonia sp. nov. bears similarities to A. pruemensis. The German species is easily discriminated by the more smoothly rounded, somewhat parabolic cephalic outline, the finer genal spines with deep furrows, and the presence of "pores" instead of exclusively tubercles on the pygidium. Furthermore similar is A. lauchensis Basse, 2003 from the (?)Lauch Formation in the Eifel but that species was established on a single damaged pygidium. As far as it can be compared with our material from F-032 it is different in having narrower pygidial pleural spines with less pronounced tubercles. Basse (2003) recorded a second pygidium from the Lauch Formation that he tentatively assigned to his species while commenting that its morphology is not very representative.

Family Phacopidae Hawle \& Corda, 1847

Subfamily Phacopinae Hawle \& Corda, 1847

\section{Genus Geesops Struve, 1972}

Type species. Calymene schlotheimi Bronn, 1825.

Discussion. Geesops is restricted to the Eifelian of the Ardenno-Rhenish Mountains. Relationships with the putatively paraphyletic Morocops Basse, 2006 from the Emsian to earliest Eifelian of Morocco were discussed by van Viersen et al. (2017b), who suggested that a descendant of the latter was first able to cross the Rheic Ocean in the earliest Eifelian. Notwithstanding 

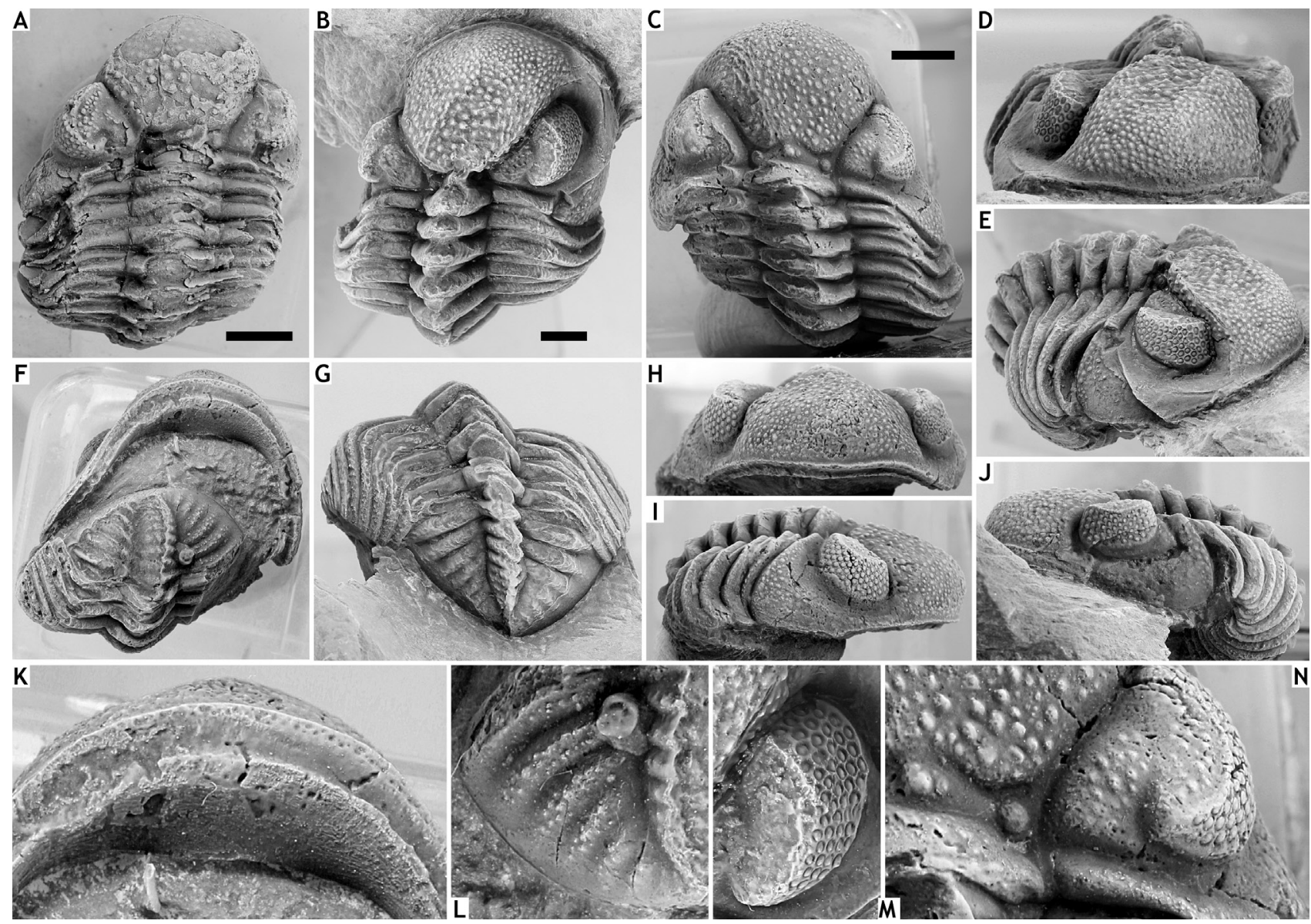

Figure 6. Geesops gallicus Struve, 1982 from the Vieux Moulin Member of the Jemelle Formation at F-032, Vireux-Molhain. All specimens have the cuticle preserved.

A. Complete specimen, IRSNB a13315, in dorsal view.

B, D, E, G, J, M. Complete specimen, IRSNB a13316, in dorsal (B), anterior (D), oblique anterolateral (E), dorsal view of pygidium (G), lateral (J) views and close-up of right eye $(\mathrm{M})$.

C, F, H, I, K, L, N. Complete specimen, IRSNB a13317, in dorsal view of cephalon (C), dorsal view of pygidium (F), anterior (H) and lateral (I) views, and ventral view of cephalon $(\mathrm{K})$, close-up of pygidium $(\mathrm{L})$ and close-up of cephalon $(\mathrm{N})$.

All scale bars represent $5 \mathrm{~mm}$.

the similarities between early Eifelian Morocops and Geesops species, the middle Eifelian marks a change in the general morphology of Geesops: the glabella becomes narrower (tr.), the maximum amount of lenses per dorsoventral file increases (to up to seven) and so the eye becomes taller. The tubercles centrally on the glabella become larger, often bladder-like or sometimes coneshaped, and more widely spaced. This trend arguably endured through potential transitory forms such as Geesops? dolosus (Struve, 1970) and species of Nyterops in the upper Eifelian to Lower Givetian.

\section{Geesops gallicus Struve, 1982}

(Fig. 6)

* 1982b Geesops sparsinodosus gallicus Struve, pp. 478, 479, pl. 1 figs 1-6.

? 2000 Phacops (Phacops) sparsinodosus gallicus (Struve 1982); Schraut, p. 533, fig. 8d-f.

Material. IRSNB a13315 (Fig. 6A), IRSNB a13316 (Figs 6B, D, E, G, J, M), IRSNB a13317 (Figs 6C, F, H, I, K, L, N), three articulated specimens from F-032, Vireux-Molhain; Vieux Moulin Member of the Jemelle Formation.

Discussion. The identity of this species is ambiguous. Struve (1982b) selected an internal mould of a complete specimen as the holotype. No subsequent worker has had any problems with assigning the numerous poorly preserved specimens from the type locality (F-032) to G. gallicus, under the implicit assumption that a single species occurs there. Our Geesops material from F-032 is inclusive of at least two distinct forms, both of which might be considered conspecific with the holotype: one (e.g. Fig. 6A) has comparatively few, large tubercles on the glabella, numerous tubercles on the palpebral lobe, and large subquadratical L1; the other (e.g. Fig. 6C) has numerous smaller tubercles, a row of tubercles along the edge of the palpebral lobe, and small, rounded L1. Schraut (2000, p. 533, fig. 8d-f) recorded the hitherto best preserved Geesops specimen known from F-032. It has dorsoventrally low eyes with maximally four lenses per dorsoventral files, as against five in all our specimens and the holotype. It also has the palpebral lobe lower than the palpebral area, among other features to potentially link it to Morocops (van Viersen et al., 2017b).

Our two forms cannot be compared with the holotype because the latter is too poorly preserved. We contemplated on submitting a case to the ICZN for the replacement of the unidentifiable namebearing type of G. gallicus by a neotype. None of our specimens, however, are eligible because they are all inadequately preserved. IRSNB a13317 (Figs 6C, F, H, I, K, L, N) would currently be the best choice but despite its well-preserved right side the entire specimen is tectonically distorted. This is problematic because the proportions of the cephalon in phacopids are characteristic and differ per species. As an intermediate solution we retain the current arbitrary assignments to G. gallicus until a suitable candidate neotype is found. In our opinion, Schraut's (2000) 


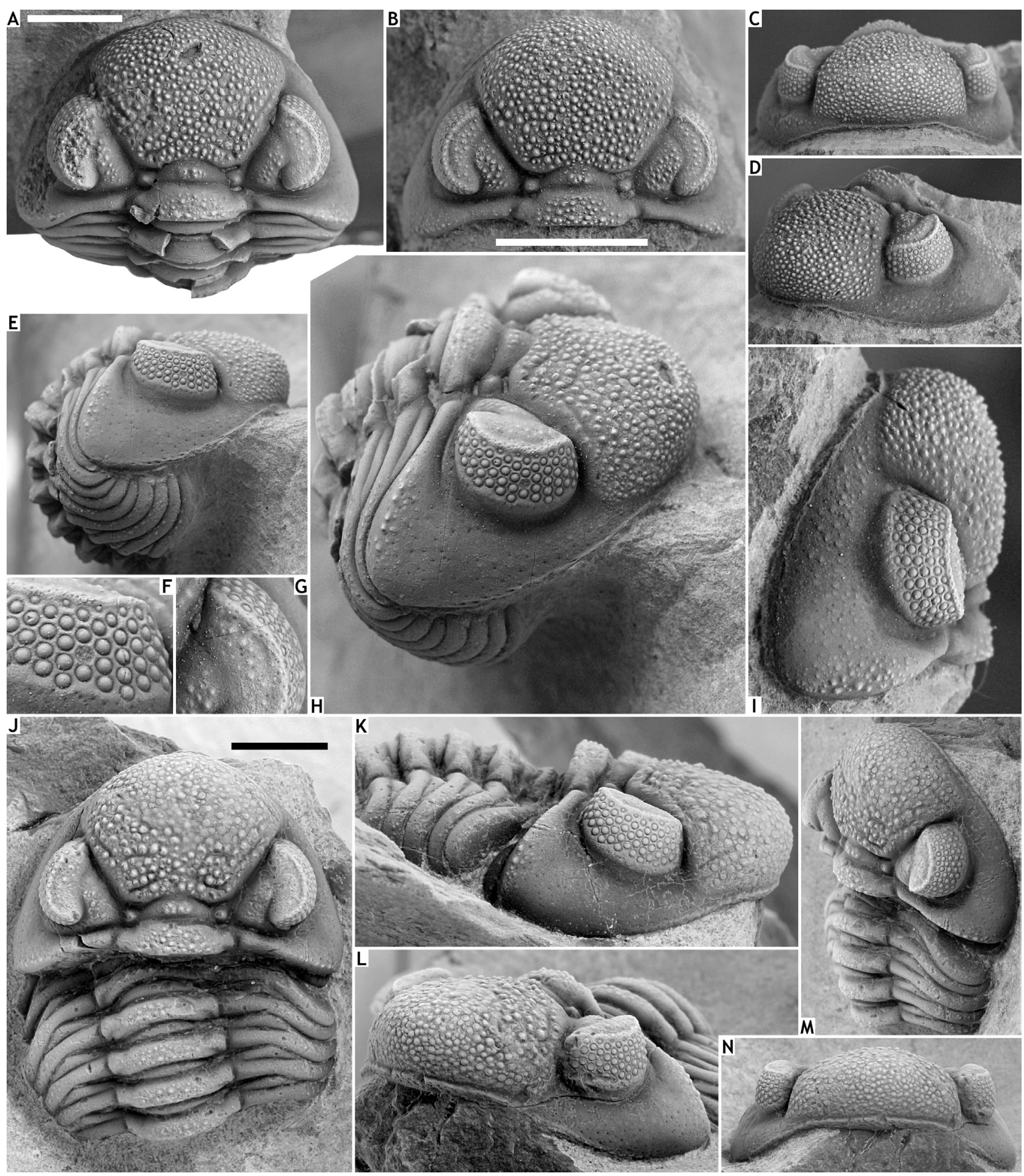

Figure 7. Geesops cf. icovellaunae sp. nov. from the Vieux Moulin Member of the Jemelle Formation at B-130, Nismes.

A, E-H. Cephalon with several thoracic tergites attached, IRSNB a13312, in dorsal (A), lateral (E), close-up of right eye (F) close-up of right palpebral lobe $(\mathrm{G})$ and oblique anterolateral $(\mathrm{H})$ views.

B-D, I. Cephalon, IRSNB a13313, in dorsal (B), anterior (C), oblique anterolateral (D) and lateral (I) views.

Geesops icovellaunae sp. nov. from the Vieux Moulin Member of the Jemelle Formation at B-079, Vierves.

J-N. Holotype cephalon with several thoracic tergites attached, IRSNB a13314, in dorsal (J), lateral (K), oblique anterolateral (L), oblique lateral (M) and anterior $(\mathrm{N})$ views.

All scale bars represent $5 \mathrm{~mm}$.

specimen stands isolated in that it differs in important aspects from our two forms and the holotype. Although it almost certainly represents a new species, we see no reason to doubt its assignment to this genus.

To summarise, there are potentially up to three distinct members of Geesops that occur in the F-032 locality. Although this number would be unprecedented in the Ardenno-Rhenish Mountains, it is not inconceivable since F-032 is a fairly large section that has been sampled intensively for decades without stratigraphic control. I.e., all three taxa do not necessarily cooccur here.

Geesops icovellaunae sp. nov.

(Figs 7J-N)

Etymology. After the eponymous Celtic goddess. 
Holotype. IRSNB a13314, cephalon with several thoracic tergites attached.

Type locality and horizon. B-079, Vierves; Vieux Moulin Member of the Jemelle Formation.

Diagnosis. Posterior border bearing several large tubercles with smaller ones scattered anterior of these. Visual surface containing 18/4 lenses, irregularly with a small fifth lens at the top. Lateral glabellar furrows S2, S3a and S3p firmly impressed. Broad (tr.), largely smooth lateral border bearing few pits centrally and abaxially; sometimes alternated by very rudimentary tubercles. Glabella with distinct anterior overhang; bearing large tubercles of similar size everywhere, infrequently alternated by isolated smaller ones. Weakly inflated border ridge, only developed anteriorly and anterolaterally, mostly recognisable by terrace ridges. Thoracic pleurae bearing few tubercles distally; otherwise smooth.

Discussion. Morphologically similar is Geesops miles Basse, 1998 from the Hobräck Formation (lower Eifelian) in the Sauerland (Rhenish Mountains). Cephalic parts were recorded by Basse $(1998,2006)$ but these are incomplete and have not been photographed from multiple angles. Nevertheless, G. miles is principally different in having a more inflated intercalating ring, finer sculpture on the glabella, comparatively weakly impressed lateral glabellar furrows, and much denser tuberculation on the thoracic axial rings and pleurae. Geesops synapticus Struve, 1982 from the basal Kirberg Member of the Nohn Formation in the Eifel is similar to G. miles and G. icovellaunae sp. nov. but distinct in having much reduced tuberculation (both in density and size), larger L1, and weakly impressed lateral glabellar furrows. Although we are convinced that these three species are distinct, thus warranting the description of $G$. icovellaunae as a new species, additional material (especially pygidia) from Belgium and Germany will be required in order to come to a better division.

A comparison with Geesops gallicus is pointless as long as a neotype has not been selected. The only comparatively well-preserved specimen is IRSNB a13317. It lacks distinctive features of $G$. icovellaunae such as the firmly impressed S2, S3a and S3p, and the specific lens configuration with maximally 4 (intermittently 5) lenses per dorsoventral file.

\section{Geesops cf. icovellaunae sp. nov.}

(Figs 7A-I)

Material. IRSNB a13312 (Figs 7A, E-H), cephalon, IRSNB a13313 (Figs 7B-D, I), cephalon with thoracic tergites attached, IRSNB a13307b (not figured), cephalon, from the Vieux Moulin Member of the Jemelle Formation at B-130, Nismes.

Discussion. The specimens from B-130 are very similar to the holotype of G. icovellaunae from B-079. They differ mainly in that the glabella lacks anterior overhang and bears smaller, more densely spaced tubercles centrally on the glabella. Tubercles become even smaller towards the anterior and anterolateral parts of the glabella whereas in the holotype they are hardly of reduced size in these areas. Additional specimens of both species, including well-preserved pygidia, are needed to conduct a more detailed comparison and assess any intraspecific variation.

\section{Genus Pedinopariops Struve, 1972}

Type species. Phacops (Phacops) lentigifer Struve, 1970.

\section{Pedinopariops ceuthonymus sp. nov.}

(Fig. 8)

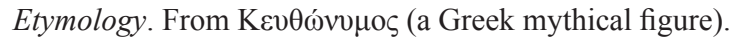

Holotype. IRSNB a13310, enrolled specimen with fragmentary pygidium (Figs 8A-E).

Paratype. IRSNB a13311, tectonically deformed, enrolled complete specimen (Figs 8F-I).

Type locality and horizon. F-032, Vireux-Molhain; Vieux Moulin Member of the Jemelle Formation.

Diagnosis. Large, weakly inflated, bladder-like tubercles centrally on glabella. Moderately firmly impressed S2 and
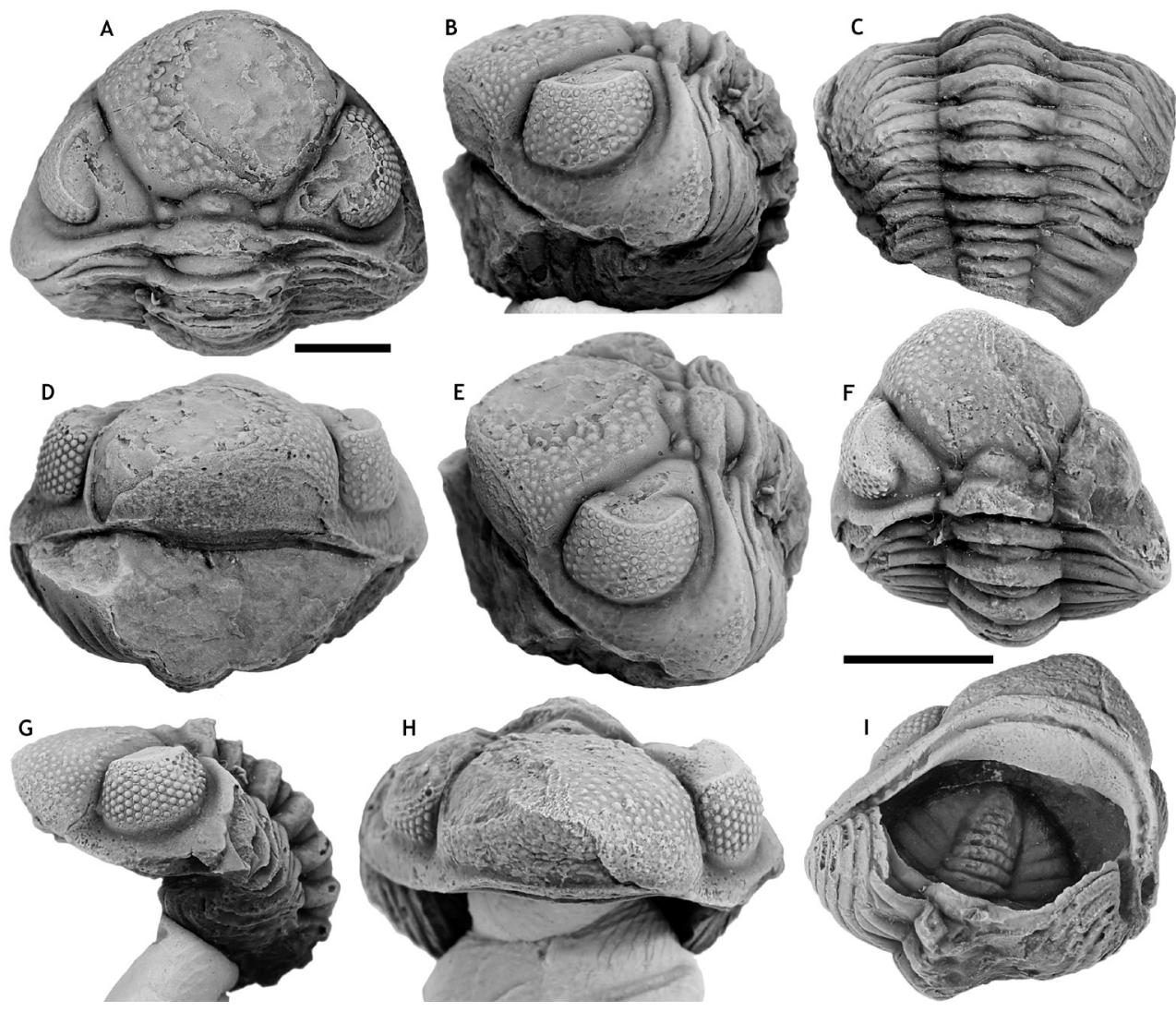

Figure 8. $\quad$ Pedinopariops ceuthonymus sp. nov. from the Vieux Moulin Member of the Jemelle Formation at F-032, Vireux-Molhain.

A-E. Holotype enrolled specimen, IRSNB a13310, in dorsal (A), lateral (B), dorsal view of pygidium $(\mathrm{C})$, anterior (D) and oblique lateral (E) views. F-I. Paratype enrolled specimen, IRSNB a13311, in dorsal (F), lateral $(\mathrm{G})$, anterior $(\mathrm{H})$ views and dorsal view of pygidium (I). All scale bars represent $5 \mathrm{~mm}$. 


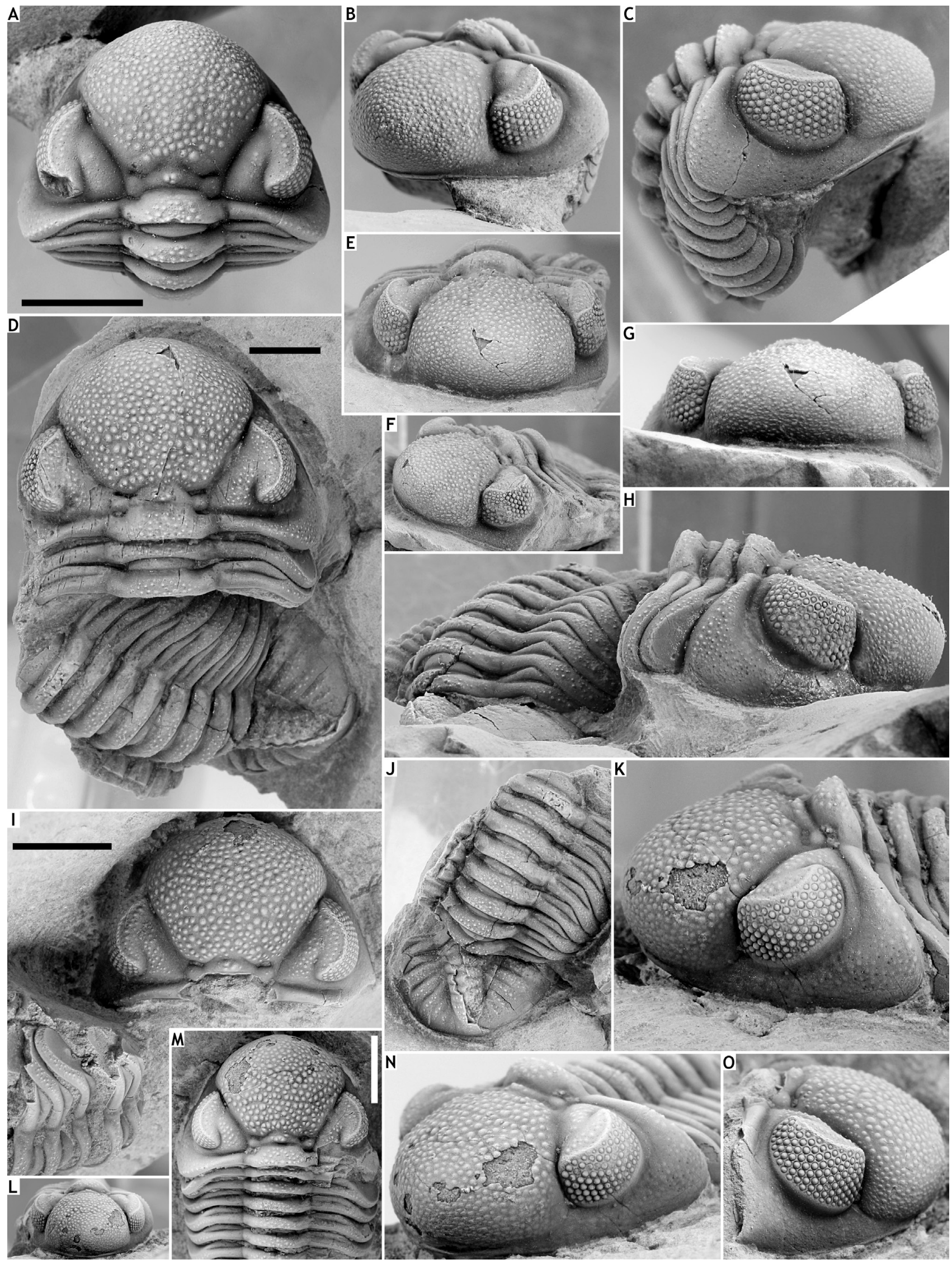

Figure 9. Pedinopariops richterianus geminus ssp. nov. from the Vieux Moulin Member of the Jemelle Formation at B-130, Nismes. A-C. Paratype cephalon with attached thoracic tergites, IRSNB a13307a, in dorsal (A), oblique anterolateral (B) and lateral (C) views.

D-H, J. Holotype complete specimen, IRSNB a13308, in dorsal (D), oblique anterior (E), oblique anterolateral (F), anterior (G) and lateral (H) views, and dorsal view of pygidium $(\mathrm{J})$.

I, O. Paratype cephalon plus dissociated partial thorax, IRSNB a13309b, in dorsal (I) and lateral (O) views.

K-N. Paratype cephalon with attached thoracic tergites, IRSNB a13309a, in lateral (K), oblique anterior (L), dorsal (M) and oblique anterolateral (N) views.

All scale bars represent $5 \mathrm{~mm}$. 
S3p. Weakly impressed palpebral furrow. Palpebral area and lobe devoid of sculpture. Visual surface containing 18/8 lenses. Thoracic and pygidial axial rings bearing large tubercles. Thoracic and pygidial pleurae devoid of sculpture. Pygidium with narrow (exsag.) pleural furrows and rudimentary interpleural furrows.

Discussion. The morphologically closest form is probably the somewhat problematic (see Basse, 2006) Pedinopariops erebeus Struve, 1992 from the Kirberg Member of the Nohn Formation in the Eifel. That species differs from ours in having a more inflated intercalating ring that is covered with several tubercles, more inflated tubercles on the glabella, firmly impressed S2 and $\mathrm{S} 3 \mathrm{a}+\mathrm{p}$, densely spaced tubercles on the palpebral area and lobe, less developed postocular pad with the eye positioned closer to the posterior border. The thorax and pygidium of $P$. erebeus are not known with certainty. This impedes a comparison of these parts with the new species.

\section{Pedinopariops richterianus (Struve, 1970)}

Subspecies assigned. P. richterianus richterianus from the Lauch Formation in the Eifel; P. richterianus geminus ssp. nov. from the Jemelle Formation in the Ardennes.

\section{Pedinopariops richterianus geminus ssp. nov.}

(Fig. 9)

Etymology. From geminus (Latin; twin). $\mathrm{J})$.

Holotype. IRSNB a13308, complete specimen (Figs 9D-H,

Paratypes. IRSNB a13307a (Figs 9A-C), cephalon with attached thoracic tergites, IRSNB a13309a (Figs 9K-N) and 13309b (Figs 9I, O), cephalon with attached thoracic tergites and cephalon plus dissociated partial thorax on the same rock slab, from type locality and horizon.

Type locality and horizon. B-130, Nismes; Vieux Moulin Member of the Jemelle Formation.

Differential diagnosis. Glabella with distinct anterior overhang. Small tubercles on glabella that are never amalgamated. Wide (tr.) palpebral lobe and area.

Discussion. The specimens from Belgium are similar to $P$. richterianus richterianus from the (?)Wolfenbach Member of the Lauch Formation in the Eifel and are contrasted as stated above. Only two topotype cephala of the nominal subspecies have been illustrated in the literature (see Basse, 2006, pl. 11, figs 99-101); additional material (especially pygidia) will be needed for a more detailed comparison.

Family Proetidae Salter, 1864

Subfamily Proetinae Salter, 1864

\section{Genus Gerastos Goldfuss, 1843}

Type species. Proetus cuvieri Steininger, 1831.

Gerastos catervus (van Viersen, 2006)

(Figs 10; 11A-L)

v * 2006a Rhenocynproetus catervus van Viersen, p. 66, pl. 2, figs $1-8$

v 2008 Gerastos catervus; van Viersen \& Prescher, p. 13, pl. 1 , figs $6,9,10,14$ [with a list of synonyms].

v 2012 Gerastos catervus; van Viersen \& Daumeries, p. 9, fig. B, p. 10, figs A-C, p. 12.

Material. IRSNB a13302-13306 (Figs 10A-O), five complete specimens, PLI-06 (Figs 10P-S), silicone cast of fragmentary external mould of cephalon, from F-032, Vireux-Molhain. IRSNB a13299a (Figs 11A, B, G) and a13299b (Figs 11C-H), a complete specimen and a cephalon plus thoracic tergites on a single rock slab, IRSNB a13275 (not figured), a single librigena, from B-079, Vierves. IRSNB a13300 (Figs 11I-L), complete specimen, from B-130, Nismes. All from Vieux Moulin Member of the Jemelle Formation.

Revised diagnosis. Widely rounded cephalon of semi-circular to subtrapezoidal outline. Lateral occipital lobes adaxially welldemarcated by deep furrows, bearing small tubercles. Broad glabella bearing numerous, closely spaced tubercles of varying sizes and shapes. Moderately large eyes. Subocular ridge inflated throughout, bearing fine granules or devoid of these, separated from eye socle by a broad furrow. Librigenal field covered with weakly expressed pit-like depressions. Angular genal corner, often with a short spine. Pygidium devoid of sculpture; bearing fine pores on posterior to posterolateral border.

Discussion. Gerastos catervus is a common species at the type locality (F-032) and copious topotype specimens have been available for study. Only few of these are suitable for a description since most are poorly preserved and tectonically deformed. Van Viersen (2006a) designated a complete specimen with the cuticle preserved holotype although it is clearly deformed. As far as the type can be compared to the specimens recorded herein there are no significant differences, except for the fewer, larger tubercles on the glabella of some (e.g. Figs 10D, Q). A revised diagnosis is provided here because the original is insufficient to distinguish G. catervus from other species. The arbitrary assignments of Gerastos specimens from the F-032 locality to G. catervus is similar to the case of Geesops gallicus in that some morphologic variation exists, although in the former this is restricted to glabellar sculpture. Future studies may warrant subdivision of $G$. catervus.

Gerastos catervus is generally similar to Gerastos kippingi van Viersen \& Prescher, 2010 from the Nohn Formation (Kirberg Member) in the Eifel. The German species is discriminated by its smooth lateral occipital lobes and anteriormost part of glabella, a less pronounced subocular ridge with smaller furrow separating it from eye socle, well-developed apodemes on posterior pygidial axial rings, more firmly impressed pygidial pleural furrows, and sculpture on pygidium consisting of tubercles.

\section{Gerastos kesselaeri sp. nov.}

(Figs 11M-Q)

Etymology. Named after Ivo Kesselaer, in recognition of his support for this study.

\section{Holotype. IRSNB a13301, complete specimen.}

Type locality and horizon. B-130, Nismes; Vieux Moulin Member of the Jemelle Formation.

Diagnosis. Dorsally flattened anterior to lateral cephalic border. Occipital ring with far posteriorly positioned median tubercle. Wide (tr.) palpebral lobes. Large eyes. Weakly vaulted (tr.) librigenal field. Long, somewhat outward directed librigenal spines. Elongated ovoid-shaped glabella in dorsal view; subtrapezoidal in anterior view. Small pygidium with weakly defined pygidial border.

Discussion. This species bears many similarities to Gerastos tuberculatus marocensis Chatterton et al., 2006 from the upper Emsian of Morocco. The latter is contrasted by its smaller lateral occipital lobes, shorter, more inflated (sag., tr.) cephalon with shorter glabella, more inflated subocular ridge separated from eye socle by a broader furrow, inflated cephalic border with deep border furrow (especially anteriorly), pygidium with better developed apodemes on axial rings 1-5, pygidial border separated from pleural fields by a marked (subhorizontal) change of inclination, and richer dorsal sculpture on pygidium consisting of numerous tubercles. 

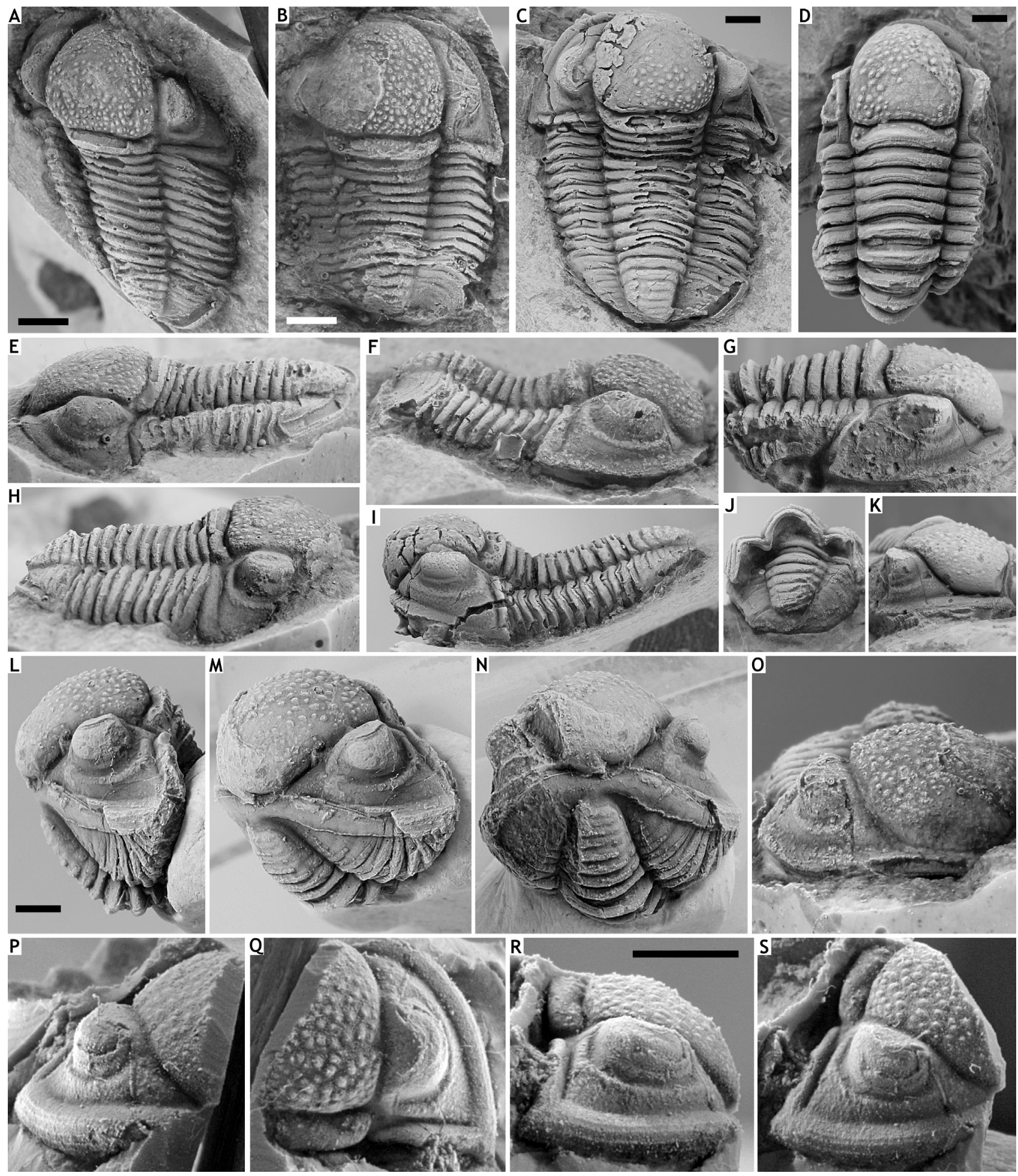

Figure 10. Gerastos catervus (van Viersen, 2006) from the Vieux Moulin Member of the Jemelle Formation at F-032, Vireux-Molhain.

A, E, H. Silicone cast of external mould of complete specimen, IRSNB a13305, in dorsal (A), left lateral (E) and right lateral (H) views.

B, F, O. Silicone cast of external mould of complete specimen, IRSNB a13306, in dorsal (B), lateral (F) and anterior (O) views.

C, I. Partially exfoliated complete specimen (with the cuticle preserved), IRSNB a13303, in dorsal (C) and lateral (I) views.

D, G, J, K. Complete specimen (with the cuticle preserved), IRSNB a13304, in dorsal (D), lateral (G), posterior (J) and anterolateral (K) views.

L-N. Enrolled complete specimen (with the cuticle preserved), IRSNB a13302, in lateral (L), anterolateral (M) and anterior (N) views.

P-S. Silicone cast of fragmentary external mould of cephalon, PLI-06, in anterior (P), dorsal (Q), lateral (R) and oblique anterolateral (S) views.

All scale bars represent $2 \mathrm{~mm}$.

Gerastos kesselaeri also bears a resemblance to Rhenocynproetus cultrijugati (Richter \& Richter, 1918) from the Lauch Formation in the Eifel. That species has a high parabolic (sag.) cephalic outline, narrow (tr.) palpebral lobe, smaller eyes and a much larger pygidium. Van Viersen \& Prescher (2008) placed Rhenocynproetus in synonymy with Gerastos. Van Viersen \& Prescher (2010) and van Viersen et al. (2012) discussed different concepts of Gerastos and allied genera in the recent literature, concluding that there is far from consensus on their classification among workers. Basse \& Müller (2016) provided reasons for the retention of Rhenocynproetus but added that $G$. catervus, which was originally described as a Rhenocynproetus, is rightly placed in Gerastos. 

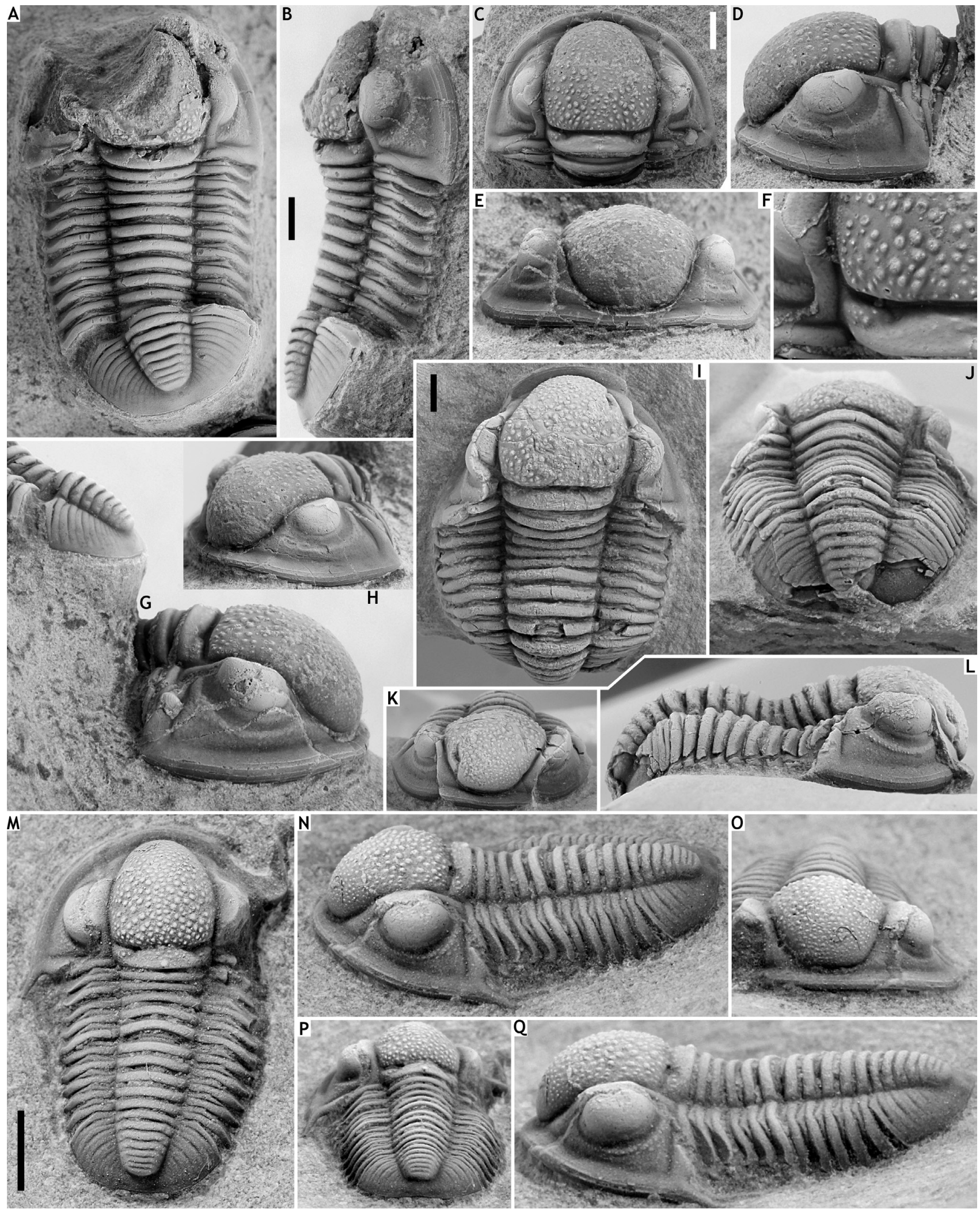

Figure 11. Gerastos catervus (van Viersen, 2006) from the Vieux Moulin Member of the Jemelle Formation at B-079, Vierves.

A, B, G. Complete specimen, IRSNB a13299a, in dorsal (A) and lateral (B) views, and lateral view of pygidium (G).

C-H. Cephalon with several thoracic tergites attached, IRSNB a13299b, in dorsal (C), left lateral (D) and anterior (E) views, close-up of posterior part of cephalon $(\mathrm{F})$, and right lateral $(\mathrm{G})$ and anterolateral $(\mathrm{H})$ views.

Gerastos catervus (van Viersen, 2006) from the Vieux Moulin Member of the Jemelle Formation at B-130, Nismes.

I-L. Complete specimen, IRSNB a13300, in dorsal (I), posterior (J), anterior (K) and lateral (L) views.

Gerastos kesselaeri sp. nov. from the Vieux Moulin Member of the Jemelle Formation at B-130, Nismes.

M-Q. Holotype complete specimen, IRSNB a13301, in dorsal (M), oblique lateral $(\mathrm{N})$, anterior $(\mathrm{O})$, posterior $(\mathrm{P})$ and lateral $(\mathrm{Q})$ views. All scale bars represent $2 \mathrm{~mm}$. 


\section{Gerastos silvicultrix sp. nov.}

(Fig. 12)

Etymology. From silvicultrix (Latin; one who inhabits woods).

Holotype. IRSNB a13296, cranidium (Figs 12A, B, E).

Paratypes. IRSNB a13297, partial pygidium (Fig. 12D) and IRSNB a13298, pygidium (Figs 12C, F), from type locality and horizon.

\section{Type locality and horizon. G-099, Ahütte; Heisdorf Formation.}

Diagnosis. Collar-shaped occipital ring with small, weakly separated lateral lobes. Short, high-vaulted (sag.), anteriorly weakly inclined glabella without anterior overhang. Anterior border gradually reduced in height anteriorly (sag.). Large, closely spaced tubercles centrally on glabella and drastically smaller ones on anterior part. Subsemicircular pygidium bearing tiny pores and rarely granules on axis; sparse, fine granules on the pleural fields; numerous granules on pygidial border. Posterior pleurae short; pygidial border is broad (exsag.) here. Long (sag.) postaxial area.

Discussion. The cranidium of Gerastos silvicultrix might have been assigned to Dohmiella, the stratigraphically earliest species of which occur in the Nohn Formation in the Eifel and Couvin Formation in the Ardennes (B-028). Besides the stratigraphic gap between these occurrences and G. silvicultrix the cranidium of the latter conforms to Gerastos rather than Dohmiella. Lütke (1990) typified Dohmiella as having distinctly incised, vaulted lateral occipital lobes. In Gerastos, including the cranidium of $G$. silvicultrix, these lobes are fused.

Basse (1998, pl. 14, fig. 2) illustrated a cranidium designated Gerastos sp. nov. S from the Heisdorf Formation in the same area (Üxheim). Although he only provided a single photo in dorsal view, the specimen appears to be different from ours in having more widely spaced tubercles and a narrower (sag., exsag.), more inflated anterior border.

Gerastos tuberculatus marocensis is different in having a generally more vaulted glabella with distinct anterior overhang, shorter anterior border and deep border furrow, smaller tubercles centrally on glabella, subtrapezoidally shaped pygidium covered with tubercles, more firmly impressed apodemes on axis, longer pleurae, well-demarcated pygidial border, and shorter postaxial field.

Gerastos kesselaeri sp. nov. is discriminated by its longer glabella with distinct anterior overhang, smaller tubercles centrally on glabella, larger, well-defined lateral occipital lobes, shorter (sag.) anterior border, longer posterior pygidial pleurae, weakly impressed pygidial interpleural furrows, and shorter postaxial field.
Subfamily Cornuproetinae Richter, Richter \& Struve in Moore, 1959

\section{Genus Diademaproetus Alberti, 1964}

Type species. Proetus holzapfeli Novák, 1890.

\section{Diademaproetus pertinax sp. nov.}

(Figs 13A-P)

Etymology. From pertinax (Latin; persistent).

Holotype. IRSNB a13293, complete specimen (Figs 13A-G).

Paratypes. IRSNB a13294, a13295 (Figs 13H-P), from B-130, Nismes; Vieux Moulin Member of the Jemelle Formation.

Type locality and horizon. B-079, Vierves; Vieux Moulin Member of the Jemelle Formation.

Diagnosis. Cephalon of weakly parabolic to somewhat subtrapezoidal outline. Occipital ring and palpebral lobes bearing a mixture of tubercles and short terrace ridges. Short, strongly vaulted (sag.) glabella anterior to S0 bearing numerous tubercles; anteriorly these are alternated by fine, short terrace ridges. Short (sag.) preglabellar field. Weakly impressed, thin (sag.) anterior border furrow; broadened abaxially and continued in unchanged form onto librigena. Anterior border in front of glabella of consistent width (sag., exsag.); bearing numerous short terrace ridges on inner half and two to three continuous terrace ridges on outer half. Anterior ledge not developed. Librigenal field bearing short terrace ridges and (only paratypes) small, evenly spaced tubercles in between. Long, thin, proximally straight and distally inward curved genal spines. Thoracic axial rings bearing short terrace ridges anteriorly and numerous tubercles posteriorly. Thoracic anterior pleural bands bearing short terrace ridges; posterior pleural bands bearing terrace ridges and distally a row of fine tubercles on posterior margin. Thoracic pleural furrows firmly impressed over their full length (tr.). Four pygidial axial rings separated by deep inter-ring furrows; a fifth ring is indistinctly separated from terminal piece. Pygidial sculpture similar to that on the thorax. Three pairs of pygidial pleurae with moderately firmly impressed pleural and interpleural furrows.

Discussion. None of the other published Diademaproetus species are similar to $D$. pertinax sp. nov. except for $D$. habenichti Basse \& Müller, 2016 from the Rupbach Shale (upper Emsian) in the Lahn Syncline (Rhenish Mountains). The German species is different in having a protruding (sag.) anterior border, weakly defined subocular pads, dorsal sculpture consisting of tubercles, and a rudimentary pygidial border.

Most members of Diademaproetus, including the type species, have a well-developed anterior ledge. This is not the case

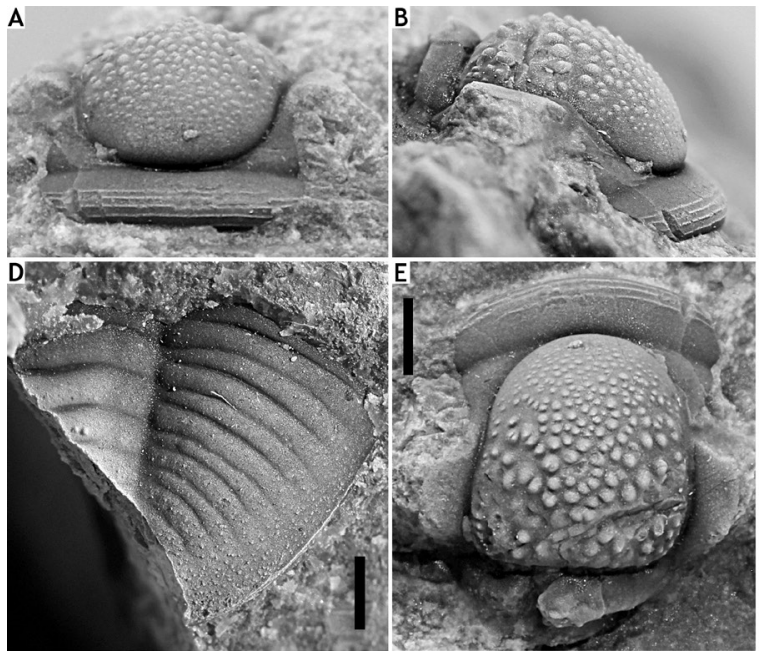

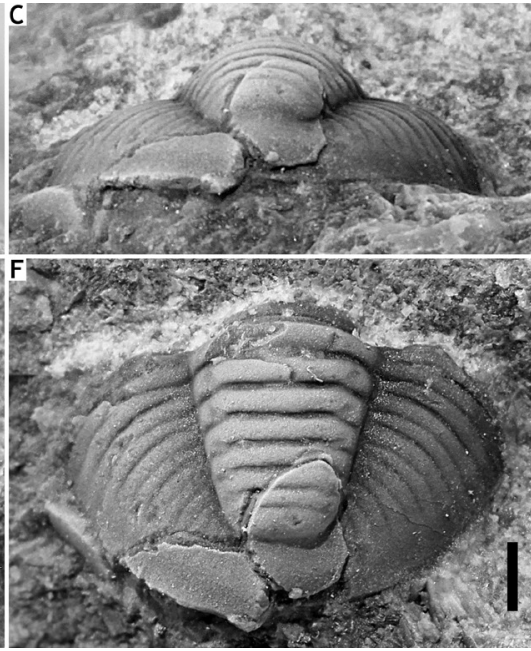

Figure 12. Gerastos silvicultrix sp. nov. from the Heisdorf Formation at B-099, Ahütte.

A, B, E. Holotype cranidium, a13296, in anterior (A), lateral (B) and dorsal (E) views.

D. Paratype partial pygidium, IRSNB a13297, in dorsal view. C, F. Paratype pygidium, IRSNB a13298, in posterior (C) and dorsal (F) views.

All scale bars represent $1 \mathrm{~mm}$. 


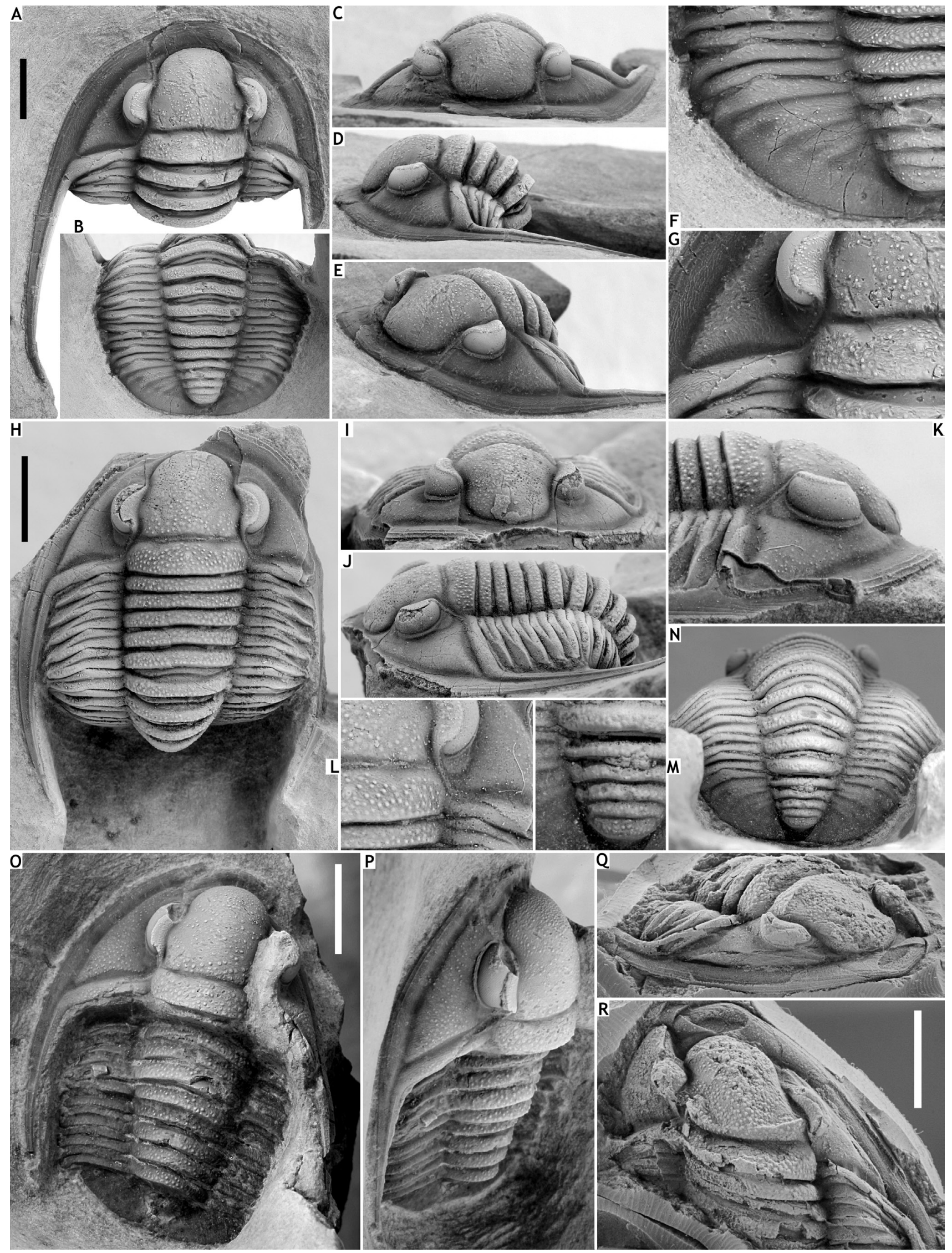

Figure 13. Diademaproetus pertinax sp. nov. from the Vieux Moulin Member of the Jemelle Formation at B-079, Vierves.

A-G. Holotype complete specimen, IRSNB a13293, in dorsal view of cephalon (A), dorsal view of pygidium (B), anterior view of cephalon (C), lateral (D) and oblique anterolateral (E) views, close-up of pygidium (F) and close-up of cephalon (G).

Diademaproetus pertinax sp. nov. from the Vieux Moulin Member of the Jemelle Formation at B-130, Nismes.

H-N. Paratype complete specimen, IRSNB a13294, in dorsal view of cephalon (H), anterior (I), left lateral (J) and right lateral (K) views, close-up of cephalon (L), close-up of pygidial axis $(\mathrm{M})$ and dorsal view of pygidium $(\mathrm{N})$.

O, P. Paratype complete specimen, IRSNB a13295, in dorsal (O) and oblique lateral (P) views.

Diademaproetus cf. pertinax sp. nov. from the Vieux Moulin Member of the Jemelle Formation at F-032, Vireux-Molhain.

Q, R. Silicone cast of external mould of partial cephalothorax, IRSNB a12612, in oblique anterolateral (Q) and dorsal (R) views.

All scale bars represent $5 \mathrm{~mm}$. 
for $D$. pertinax. However, for the rest our species adheres fully to the revised generic diagnosis of Chatterton et al. (2006) and is best assigned this genus. Basse \& Müller (2016) divided members of this genus into provisional groups and subgroups. The lack of an anterior ledge suggests that $D$. pertinax is a member of subgroup B2.

The paratypes from B-130 show subtle differences from the holotype in having dorsal sculpture with tubercles dominating over terrace ridges, weakly impressed pygidial pleural and interpleural furrows, and a more weakly defined pygidial border. Based on the currently (limited) available material we are inclined to regard these differences as intraspecific variation.

Apart from a well-developed anterior ledge, Diademaproetus dianae van Viersen, 2015 from the Jemelle Formation (middle Eifelian part) in the Couvin area is different from the new species in having an exceedingly wide (tr.) occipital ring with sigmoidally curved nearby axial furrow, short and broad genal spines, a more vaulted (sag., exsag.) pygidial border and posterior pleural bands running onto the border.

\section{Diademaproetus cf. pertinax sp. nov.}

(Figs 13Q, R)

v 2008 Diademaproetus? sp.; van Viersen \& Prescher, pp. 19, 20, fig. 5 .

Material. IRSNB a12612, external mould of a partial cephalothorax plus silicone cast, from F-032, Vireux-Molhain; Vieux Moulin Member of the Jemelle Formation.

Discussion. This specimen was previously recorded by van Viersen \& Prescher (2008) who assigned it to Diademaproetus with question because of its insufficient preservation. Basse \&
Müller (2016) commented on this classification, claiming that the presence of closely spaced tubercles on the glabella suggests that it is a member of Cornuproetus instead. The descriptions of wellpreserved specimens of $D$. pertinax sp. nov. at the nearby B-079 and B-130 localities which are generally similar and have closely spaced tubercles on the glabella now allow for a more accurate identification.

Subfamily Tropidocoryphinae Přibyl, 1946

\section{Genus Tropidocoryphe Novák, 1890}

Type species. Proetus filicostatus Novák, 1890.

\section{Tropidocoryphe insciens sp. nov.}

(Fig. 14)

v cf. 2006 Tropidocoryphe barroisi; Magrean, p. 68, pl. 1, figs 3-6.

Etymology. From insciens (Latin; unaware).

Holotype. IRSNB a13289, cephalon (Figs 14A-C).

Paratypes. IRSNB a13290 (Figs 14D, E), pygidium, IRSNB a13291 (Figs 14F-H), cephalon with thoracic tergites attached, from type locality and horizon. IRSNB a13292 (Figs 14I, J), pygidium, from B-079, Vierves; Vieux Moulin Member of the Jemelle Formation.

Type locality and horizon. B-130, Nismes; Vieux Moulin Member of the Jemelle Formation.
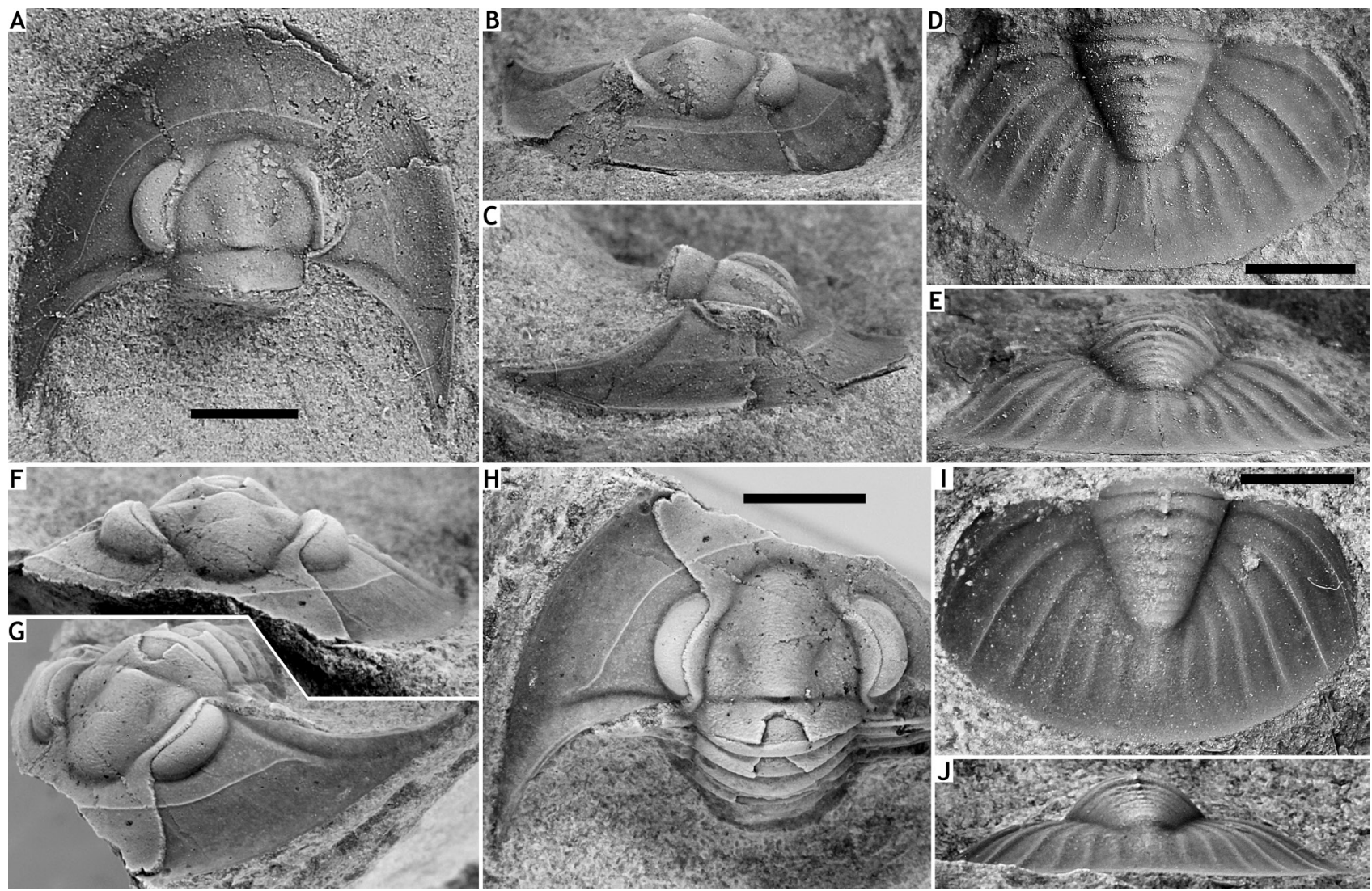

Figure 14. Tropidocoryphe insciens sp. nov. from the Vieux Moulin Member of the Jemelle Formation at B-130, Nismes.

A-C. Holotype cephalon, IRSNB a13289, in dorsal (A), anterior (B) and lateral (C) views.

D, E. Paratype pygidium, IRSNB a13290, in dorsal (D) and posterior (E) views.

F-H. Paratype cephalon with attached thoracic tergites, IRSNB a13291, in anterior (F), oblique anterolateral (G) and dorsal (H) views.

Tropidocoryphe insciens sp. nov. from the Vieux Moulin Member of the Jemelle Formation at B-079, Vierves.

I, J. Paratype pygidium, IRSNB a13292, in dorsal (I) and posterior (J) views.

All scale bars represent $2 \mathrm{~mm}$. 
Diagnosis. Cephalon of parabolic outline. Librigenal field devoid of ornament except for fine granules adaxial of the tropidium. Glabella covered with fine, very short, closely spaced terrace ridges. Large eyes. "Caecal" ridges, S2 and S3 not developed. Weakly upturned anterior and lateral cephalic borders. Short, posteriorly directed genal spines. Seven pygidial axial rings, the first five of which bear a posteromedian node. Six pairs of pygidial pleurae plus a weakly indicated anterior band of a seventh pair. Anterior two pairs of pleurae curved posteriorly about half-way (tr.) along the pleural field, remaining pairs substraight.

Discussion. None of the Tropidocoryphe species from the Ardenno-Rhenish Mountains come really close to $T$. insciens except perhaps for T. bergica Basse, 1997 from the lower Eifelian in the Bergisches Land (Rhenish Mountains). The holotype is an internal mould of an incomplete specimen. As far as it can be compared it has smaller eyes, deep, exsagittally running S1 and a smaller pygidial axis.

Tropidocoryphe erbeni Morzadec, 1969 from the upper Emsian in Brittany is different from T. insciens in having a spine on the occipital ring, bifurcate "caecal" ridges running from the glabella anteriorly on the preglabellar field, smaller eyes, more laterally directed genal spines, a more upturned anterior cephalic border, and a narrower pygidial axis.

Tropidocoryphe barroisi (Maillieux, 1904) was originally described from the Jemelle Formation (middle part) in the Couvin area. Magrean (2006) recorded pygidia of this species from the Jemelle Formation (middle Eifelian part) in the Jemelle area and from the Nohn Formation in the Eifel. Although they are generally similar, both these pygidia are different from ours in having more laterally directed anterior three pairs of pleurae. Additionally, the pygidium from the Eifel has the widest (tr.) part of the pygidium located lateral of the fourth axial ring; thus, far more anteriorly than that of T. insciens. Van Viersen et al. (2009) restricted $T$. barroisi to a poorly preserved cast of the holotype because the holotype itself was presumed lost. Specimens from the Ahrdorf Formation in the Eifel previously assigned to Maillieux's species were transferred to T. bassei van Viersen et al., 2009. These are easily discriminated from our species by having several, often branched "caecal" ridges and dorsal sculpture generally consisting of closely spaced terrace ridges.

\section{Genus Astycoryphe Richter \& Richter, 1919}

Type species. Astycoryphe senckenbergiana Richter \& Richter, 1919.

\section{Astycoryphe rugocauda sp. nov.}

(Fig. 15)

v cf. 2006 Astycoryphe senckenbergiana; Magrean, p. 68, pl. 1 , fig. 1 .

v 2006b Astycoryphe sp.; van Viersen, p. 231.

v 2010 Astycoryphe sp. B; van Viersen \& Prescher, pl. 11, fig. 7.

Etymology. Combination of rugo (Latin; rugged) and cauda (Latin; tail).

\section{Holotype. IRSNB a13276a, pygidium (Fig. 15C).}

Paratypes. IRSNB a12718, librigena (Fig. 15B), IRSNB a13276b, cranidium (Fig. 15A), from type locality and horizon.

Type locality and horizon. B-028, Nismes; Abîme Member of the Couvin Formation.

Diagnosis. Librigenal field bearing granules adaxial of tropidium. Pygidium with seven axial rings plus terminal piece, each of which is emphasised by closely spaced granules. Six pairs of pygidial pleurae, the first two of which demarcated by a ridge (multiple ridges distally on first pair) and the remainder by double

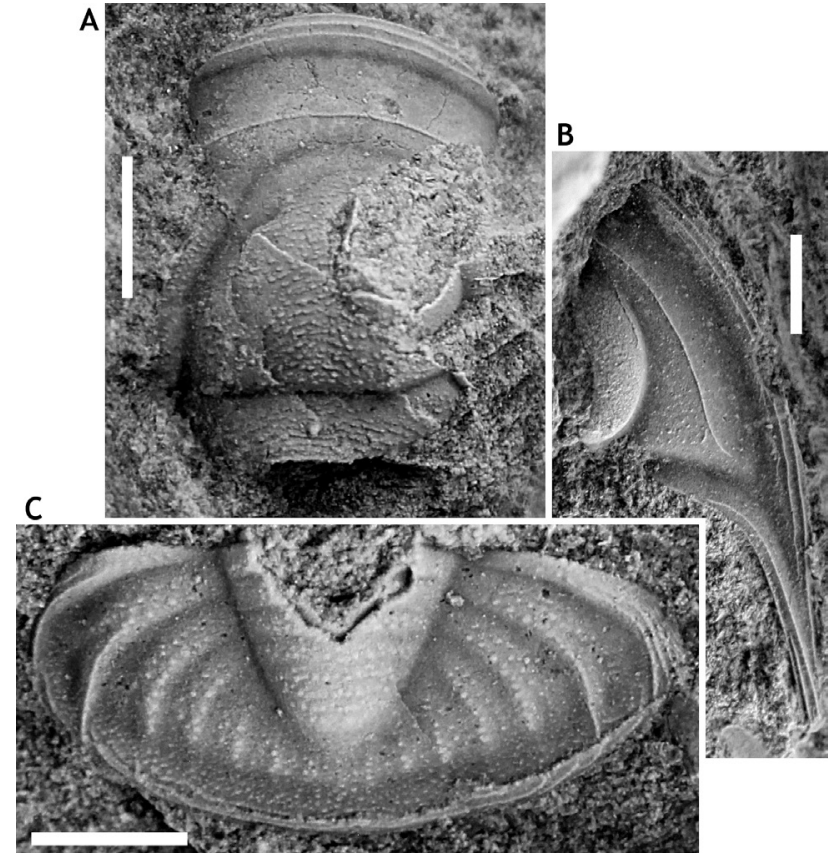

Figure 15. Astycoryphe rugocauda sp. nov. from the Couvin Formation at B-028, Nismes.

A. Paratype cranidium, IRSNB a13276b, in dorsal view. B. Paratype librigena, IRSNB a12718, in dorsal view. C. Holotype pygidium, IRSNB a13276a, in dorsal view. All scale bars represent $1 \mathrm{~mm}$

or single rows of granules. Pygidial border bearing numerous fine granules on inner half and terrace ridges on outer half.

Discussion. The morphologically closest form to $A$. rugocauda appears to be A. senckenbergiana from the Ahrdorf Formation in the Eifel. Van Viersen \& Prescher (2010) refigured the holotype of the latter and commented that its cephalon has sustained extensive damage, impeding a detailed comparison with other species. The librigena of $A$. senckenbergiana is different from that of $A$. rugocauda in having a narrower lateral border and no sculpture besides the tropidium. The pygidium of the German species differs in having a narrower (tr.) outline and axis, fewer (six) axial rings and pleural pairs (five), reduced sculpture consisting of a row of granules posteriorly on rings 3,4 and 5 (for the rest the pygidium is smooth).

Magrean (2006) recorded a pygidium from the Jemelle Formation (middle Eifelian part) in the Jemelle area that he assigned to $A$. senckenbergiana. His specimen differs from ours in bearing ridges instead of tubercles to accentuate the pleurae. Similar ridges to the Jemelle pygidium are visible in specimens from the lower Eifelian in the Eifel identified as $A$. senckenbergiana and figured by Basse (2002, pl. 28, figs 561564).

Astycoryphe arduinnae van Viersen et al., 2012 from the Jemelle Formation (middle Eifelian part) in the Couvin area is different in having the tropidium greatly reduced or absent anterior of the glabella, broader librigenal field with tropidium remaining far from lateral border furrow, widely parabolic pygidial outline, longer postaxial field, widest (tr.) point of pygidium situated lateral of second axial ring.

Family Aulacopleuridae Angelin, 1854

Subfamily Otarioninae Richter \& Richter, 1926

Tribe Otarionini Richter \& Richter, 1926

\section{Genus Cyphaspis Burmeister, 1843}

Type species. Phacops ceratophthalmus Goldfuss, 1843.

Cyphaspis insolata sp. nov.

(Figs 16A-E) 

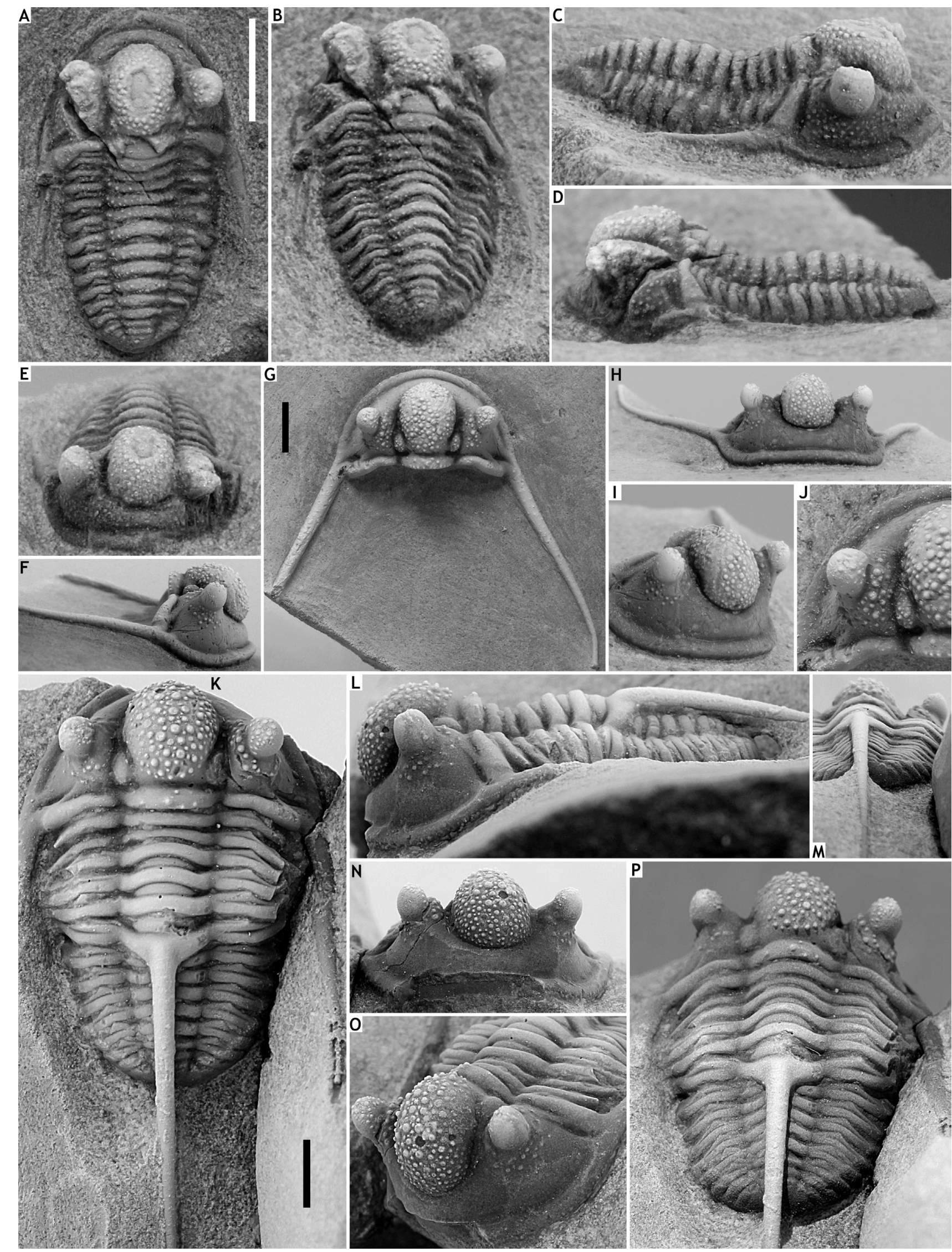

Figure 16. Cyphaspis insolata sp. nov. from the Vieux Moulin Member of the Jemelle Formation at B-130, Nismes.

A-E. Holotype complete specimen, IRSNB a13286, in dorsal (A), oblique dorsal (B), right lateral (C), left lateral (D) and oblique anterior (E) views. Cyphaspis iuxta sp. nov. from the Vieux Moulin Member of the Jemelle Formation at B-130, Nismes.

F-J. Paratype cephalon, IRSNB a13287, in lateral (F), dorsal (G), anterior (H) and anterolateral (I) views, and close-up of cephalon (J).

Cyphaspis iuxta sp. nov. from the Vieux Moulin Member of the Jemelle Formation at B-079, Vierves.

K-P. Holotype complete specimen, IRSNB a13288, in dorsal (K), lateral (L), posterior (M), anterior (N), oblique anterolateral (O) and oblique posterior (P) views.

All scale bars represent $2 \mathrm{~mm}$. 
Etymology. From insolata (Latin; unusual).

Holotype. IRSNB a13286, complete specimen (Figs 16A-E).

Type locality and horizon. B-130, Nismes; Vieux Moulin Member of the Jemelle Formation.

Diagnosis. Strongly vaulted (sag.) cephalon. Large, moderately strongly inflated glabella but without anterior overhang. Comparatively long (for a member of the hamidi group; see below), sword-shaped genal spines. Well-developed palpebral pit. Rudimentary genal trunk. Thorax bearing numerous tubercles but without a median tubercle or spine on the sixth axial ring.

Discussion. This species, with its small overall body size (compared to most other members of Cyphaspis), weakly inflated glabella, large eyes and absence of a thoracic spine, is an obvious member of the informal hamidi group as defined by van Viersen \& Holland (2016). It bears some similarities to Cyphaspis hamidi Chatterton et al., 2006 from the upper Emsian of Morocco, including the comparatively thick genal spines and large eyes. However, $C$. insolata has a less inflated glabella and long, swordshaped librigenal spines that remind of Cyphaspis kippingi van Viersen \& Holland, 2016 from the upper Emsian of Morocco. The Belgian species is discriminated from the latter in having a more strong vaulted (tr.) cephalon and glabella, larger eyes, smaller librigenae without tubercles, the lack of a dorsal spine on the sixth thoracic segment, and a more distinctly segmented pygidium.

Cyphaspis belgica van Viersen \& Prescher, 2007 from the Couvin Formation at B-028 was included in the hamidi group by van Viersen \& Holland (2016) and considered to be closely allied with Cyphaspis unguloides (Erben, 1953) and similar species from the Nohn and Ahrdorf formations in the Eifel. In particular, $C$. belgica is distinct from the new species in having a large pygidium, demonstrating a derived morphology with as many as seven axial rings (plus terminal piece) whereas the new species has four. Other differences include the anteriorly overhanging glabella of $C$. belgica and the presence of a spine on the sixth thoracic axial ring.

Cyphaspis kweberi Basse \& Müller, 2016 from the upper Emsian of the Lahn Syncline (Rhenish Mountains) is different in having a less vaulted (tr.) cephalon, larger tubercles on the glabella anterior to S0, smaller eyes, more inflated anterior to lateral cephalic borders, shorter genal spines, a thorn on the sixth thoracic axial ring, and fewer, larger tubercles on the thorax.

\section{Cyphaspis iuxta sp. nov.}

(Figs 16F-P)

Etymology. From iuxta (Latin; apposed).

Holotype. IRSNB a13288, complete specimen (Figs 16K-P).

Paratype. IRSNB a13287 (Figs 16F-J), cephalon, from B-130, Nismes; Vieux Moulin Member of the Jemelle Formation.

Type locality and horizon. B-079, Vierves; Vieux Moulin Member of the Jemelle Formation.

Diagnosis. Smoothly, widely rounded cephalon. Occipital ring bearing few randomly scattered tubercles and a median tubercle. Median glabellar lobe bearing large tubercles separated by small tubercles dorsally and a mixture of tubercles of varying sizes anteriorly. Preglabellar field devoid of tubercles. Long, evenly tapered genal spine bearing widely spaced granules. Thorax devoid of prosopon except for weakly tuberculate posterior tegimen. Robust dorsal spine on sixth thoracic segment, running subhorizontally proximally and weakly ventrally distally.

Discussion. Cyphaspis iuxta belongs to a group of species from the latest Emsian to earliest Eifelian of Morocco that includes Cyphaspis eberhardiei Chatterton et al., 2006, Cyphaspis n. sp. A of Chatterton et al. (2006) and Cyphaspis cf. eberhardiei of van Viersen \& Holland (2016). These species are all part of the Cyphaspis agayuara group of van Viersen \& Holland (2016).

Cyphaspis eberhardiei is contrasted from the new species by its parabolic cephalic outline, deeper anterior to lateral border furrows, exceedingly large tubercles crowded on the interocular field, larger tubercles on the median glabellar lobe, smaller eyes, a row of tubercles on the preglabellar field, robust, outward directed genal spine, and dorsally directed thoracic spine. Both species have fixigenal spines Fx4 retained in large holaspides as tubercles and a well-developed posterior tegimen.

\section{Cyphaspis cf. iuxta sp. nov.}

(Fig. 17)

v ? 2006a Cyphaspis n. sp. A; van Viersen, pp. 66, 67, pl. 3, figs 2-7.

v ? 2012 Cyphaspis n. sp. A; van Viersen \& Daumeries, p. 13, fig. D, p. 14.

Material. IRSNB a13282-a13285, four articulated specimens, from F-032, Vireux-Molhain; Vieux Moulin Member of the Jemelle Formation.

Discussion. The specimens from F-032 are not as wellpreserved as the holotype of Cyphaspis iuxta sp. nov. from B-079. They are only significantly different in having richer dorsal ornament and a more inflated median glabellar lobe. We include them in C. iuxta, provisionally, until additional material becomes available for comparison.

\section{Family Scutelluidae Richter \& Richter, 1955}

\section{Genus Scabriscutellum Richter \& Richter, 1956}

Type species. Bronteus scaber Goldfuss, 1843.

Discussion. The nomenclatoral stability of this genus is contested. Richter \& Richter (1956) designated a pygidium of unknown geographic and stratigraphic origin lectotype of $S$. scabrum, while assuming that the type locality and horizon must have been the Ahrdorf Formation at the famous Trilobitenfelder locality near Gees in the Eifel. Archinal (1994) and Basse in Basse \& Müller (2004) argued that an early Eifelian age for the type is much more plausible. The Scabriscutellum material from the Trilobitenfelder was assigned to a new species, $S$. vogeli, by Archinal (1994) who inadvertently selected the lectotype of S. canaliculatum (Goldfuss, 1843) as one of the paratypes (see Basse in Basse \& Müller, 2004). This means that $S$. vogeli is a junior subjective synonym of $S$. canaliculatum. Chatterton et al. (2006) overlooked these problems in revising the generic diagnosis based on two new Moroccan species known from complete specimens and material from the Ahrdorf Formation at the Trilobitenfelder identified as $S$. scabrum and figured by Kowalski (1990). In all probability, Kowalski's material belongs to $S$. canaliculatum.

Basse \& Müller (2016) erected Scabriscutellum (Rheiscutellum) to include the Moroccan species described by Chatterton et al. (2006). Rheiscutellum was discriminated mostly upon cephalic characters. The lack of a cephalon of $S$. scabrum, being the type species of Scabriscutellum, makes it difficult to validate the distinction from Rheiscutellum for it is based on the assumption that the well-preserved specimens of $S$. canaliculatum and other Scabriscutellum species are congeneric with S. scabrum. We regard these subgenera as distinct genera until a closer relationship is corroborated. The generic affiliation of Scabriscutellum archinalae sp. nov. here is provisional.

Palaeogeographically, Scabriscutellum is restricted to southern Avalonia (Belgium, Germany) according to the revised concept of Basse \& Müller (2016) whereas Rheiscutellum is Avalonian (Germany) and (peri-)Gondwanan (France, Morocco). 

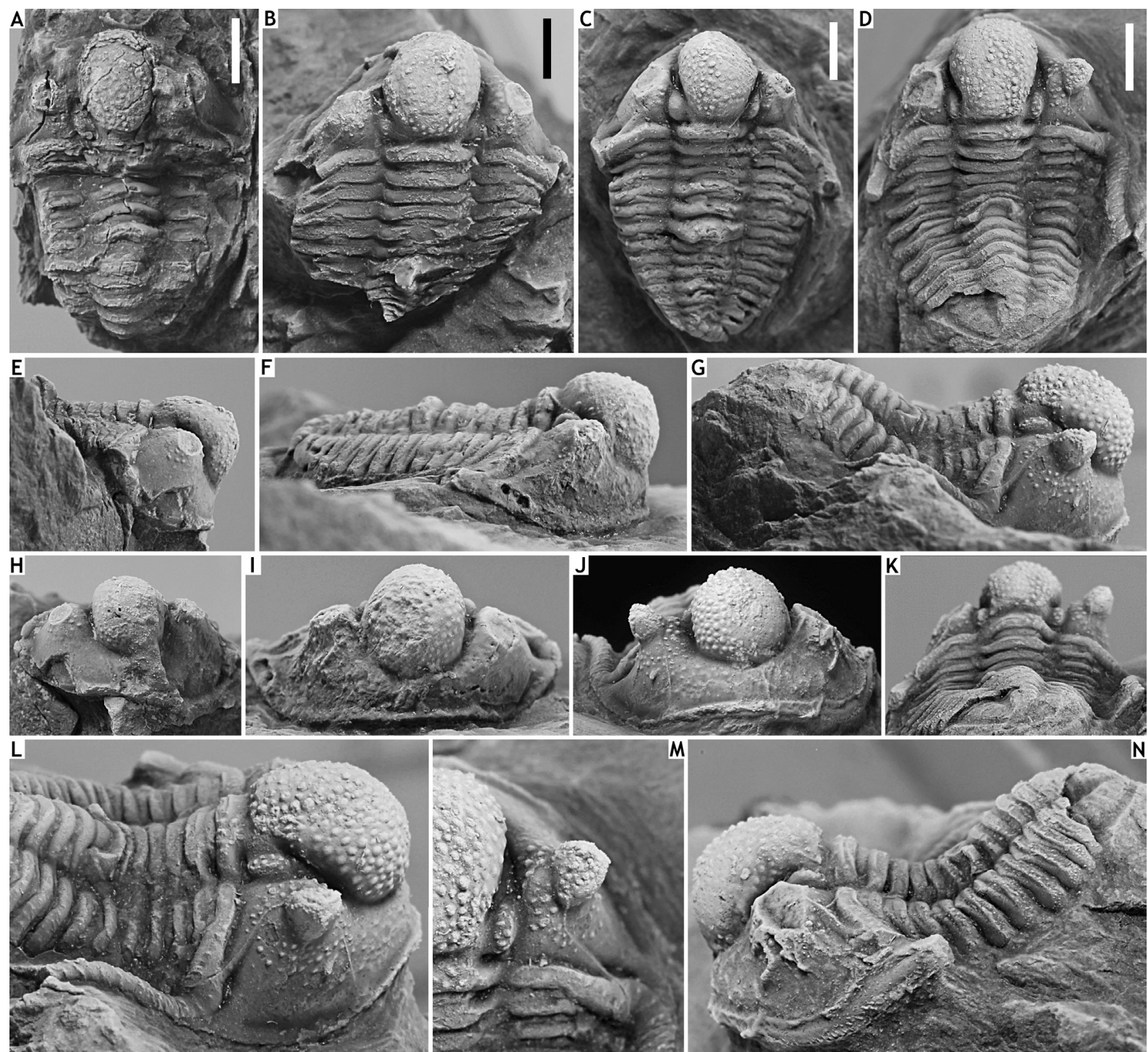

Figure 17. Cyphaspis cf. iuxta sp. nov. from the Vieux Moulin Member of the Jemelle Formation at F-032, Vireux-Molhain. All specimens have the cuticle preserved.

A. Partially exfoliated complete specimen, IRSNB a13282, in dorsal view.

B, E, H. Complete specimen, IRSNB a13283, in dorsal (B), lateral (E) and anterior $(\mathrm{H})$ views.

C, F, I. Complete specimen, IRSNB a13284, in dorsal (C), lateral (F) and anterior (I) views.

D, G, J, K-N. Complete specimen, IRSNB a13285, in dorsal (D), right lateral (G), anterior (J), posterior (K) and oblique lateral (L) views, close-up of cephalon $(\mathrm{M})$ and left lateral view $(\mathrm{N})$.

All scale bars represent $2 \mathrm{~mm}$.

\section{Scabriscutellum archinalae sp. nov.}

(Figs 18A-E)

\section{v 2013 Thysanopeltis sp.; Magrean \& Taghon, p. 76, fig. 6.}

Etymology. Named after Anne Archinal in recognition of her work on scutelluid trilobites.

\section{Holotype. IRSNB a13278, cephalon (Figs 18A-D).}

Paratype. IRSNB a13279, pygidium (Fig. 18E), from type locality and horizon.

Type locality and horizon. B-130, Nismes; Vieux Moulin Member of the Jemelle Formation.

Diagnosis. Smoothly, widely rounded cephalon. Short (sag.), dorsally flattened anterior border. Weakly expressed subocular ridge, running close to the eye. Pygidium with broad, weakly vaulted (tr.) pleurae and narrow interpleural furrows. Bifurcation of median rib positioned far posteriorly.

Discussion. The holotype cephalon was previously identified as a member of Thysanopeltis Hawle \& Corda, 1847 by Magrean \& Taghon (2013). Basse \& Müller (2016) correctly noticed that it belongs to Scabriscutellum instead.

Undetermined Scabriscutellum specimens from the Kirberg Member of the Nohn Formation in the Eifel are the known morphologically closest forms to our species. The articulated incomplete specimen figured by Archinal (1994, pl. 1, fig. 1) is contrasted by its narrower glabella, longer (sag.) anterior border, deeper lateral glabellar and cephalic axial furrows, and the longer, more posteriorly directed genal spines.

Scabriscutellum canaliculatum is principally different from our species in having a narrower (tr.) glabella between S0 and S1 and anteriorly, longer (sag.) upturned anterior border, more firmly impressed axial furrows near glabella, thinner (tr.), more vaulted pygidial ribs, and wider interpleural furrows. 


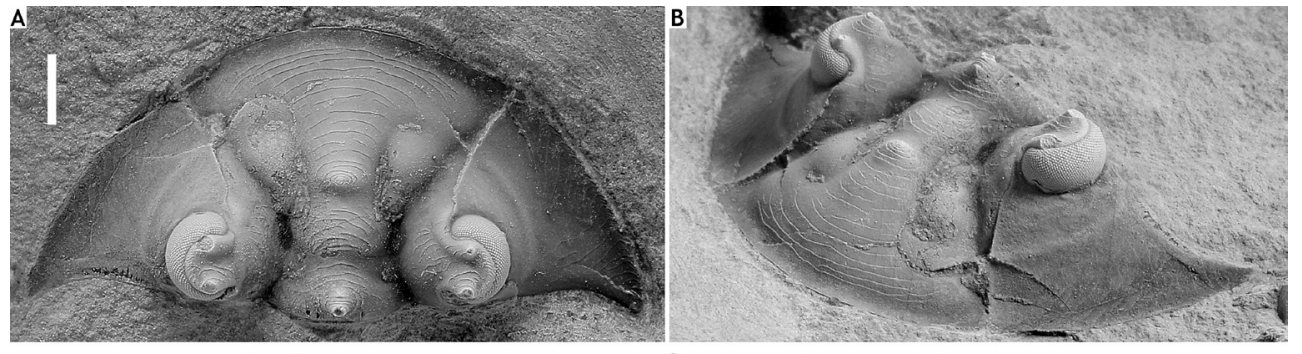

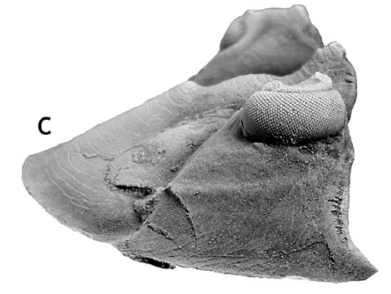
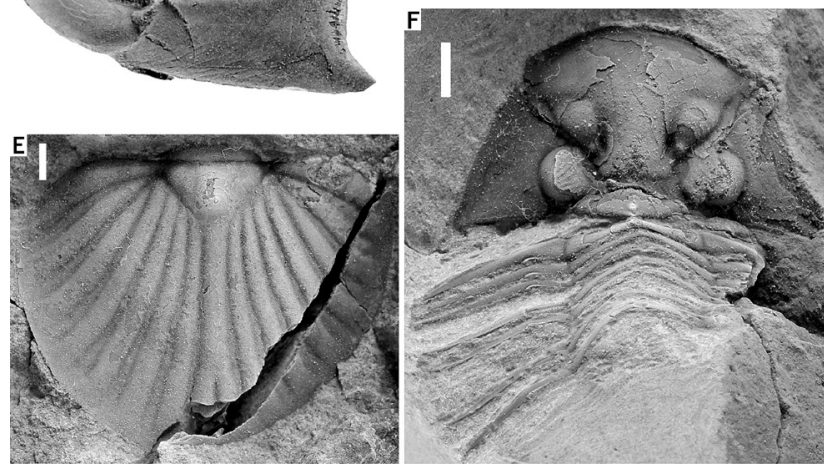

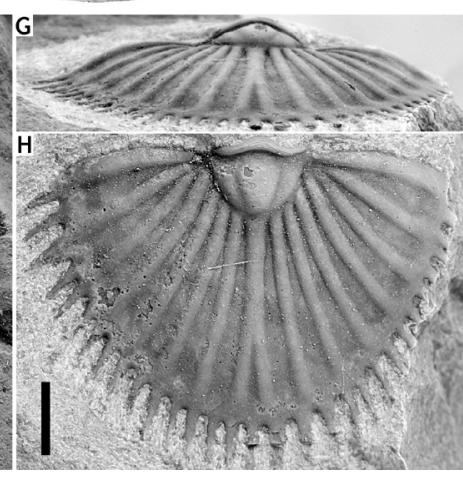

Figure 18. Scabriscutellum archinalae sp. nov. from the Vieux Moulin Member of the Jemelle Formation at B-130, Nismes.

A-D. Holotype cephalon, IRSNB a13278, in dorsal (A), oblique anterolateral (B), lateral (C) and anterior (D) views.

E. Paratype pygidium, IRSNB a13279, in dorsal view.

Septimopeltis akatastasia sp. nov. from the Vieux Moulin Member of the Jemelle Formation at B-130, Nismes

F. Paratype cephalon with thoracic tergites, IRSNB a13280, in dorsal view.

G, H. Holotype pygidium, IRSNB a13281, in posterior $(\mathrm{G})$ and dorsal $(\mathrm{H})$ views.

All scale bars represent $2 \mathrm{~mm}$.

\section{Genus Septimopeltis Přibyl \& Vaněk, 1971}

Type species. Bronteus clementinus Barrande, 1872

Discussion. Septimopeltis was erected by Přibyl \& Vaněk (1971) as a subgenus of Thysanopeltella Kobayashi, 1957 based on the pygidial morphology, which they diagnosed as semielliptical in outline and moderately vaulted; subtrigonal, vaulted, trilobate axis; seven, narrow, ridge-like pleural ribs; furrows between ribs wide, ending near pygidial border; bifurcate median rib; each rib is extended onto the border and into a long, acuminate spine. Přibyl \& Vaněk (1971) contrasted the nominal subgenus by the number of "main" border spines (15), the narrower furrows in between the broader, less vaulted ribs which are continued beyond the border as broad, short spines. These workers already suspected that Bronteus trutati Barrois, 1886 from the basal Eifelian in the French Pyrenees and Thysanopeltis magnispina Maillieux, 1938 from F-032 could belong to their new subgenus.

Basse in Basse \& Müller (2004) treated Septimopeltis as a distinct genus while recognising several groups and subgroups. The only reservation that we have about this subdivision is that many species are known from the pygidium alone. Although for the time-being these groupings are helpful, it seems unlikely that they are all natural and that they collectively represent a monophyletic Septimopeltis. A broad phylogenetic analysis that is to include Septimopeltis and Thysanopeltella but also genera such as Thysanopeltis, Rheiscutellum and Scabriscutellum would be timely. This is beyond the scope of the present paper.

\section{Septimopeltis akatastasia sp. nov.}

(Figs 18F-H)

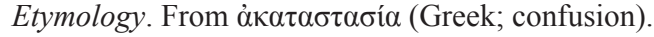

Holotype. IRSNB a13281, pygidium (Figs 18G, H).

Paratype. IRSNB a13280, cephalon with disarticulated thoracic tergites (Fig. 18F), from type locality and horizon.

Type locality and horizon. B-130, Nismes; Vieux Moulin Member of the Jemelle Formation.
Diagnosis. Cephalon of rounded subquadratical outline. Glabella very wide near $\gamma$. $\beta$ lies abaxial of lateral margin of visual surface. Occipital ring bearing a median tubercle. Anterior two thoracic axial rings bearing a distinct median tubercle. Pygidium with \pm 32 short border spines of similar length. Third border spine pair has a smaller spine just posterior of it.

Discussion. The new species is provisionally assigned to Septimopeltis based on similarities to the pygidia of other species and, more specifically, group C of Basse in Basse \& Müller (2004). Of note is that the left side of the holotype pygidium counts 16 border spines and each pleural rib is continued beyond the pygidial border as a thick spine; the third border spine has a fourth spine just posterior of it (not merged). The right side of the pygidium has 15 border spines (including the anteriormost spine which is broken off) and it seems that not all of the pleural ribs are extended into a spine. A pygidial median spine is present. Additional pygidia will be needed to assess any intraspecific variation and whether or not the condition in the holotype is anomalous.

Van Viersen (2006a) redescribed S. magnispina from F-032 ('Mur des douaniers') which is easily distinguished from the new species in having 24 border spines; towards posterior end of pygidium each spine is longer than the previous. Van Viersen (2006a) stated that a putative second Septimopeltis species occurs at F-032 which has about 30 border spines, but that the available material is very scanty (unnumb. specimen in the collections of the Katholieke Universiteit Leuven). This material, which has yet to be published, may well be closely related to the new species.

The cephalic morphology of Septimopeltis was previously known exclusively from $S$. carinthiana Feist, 1999 (cranidium alone) from the lower Eifelian of the Carnic Alps, S. cf. trutati of Basse in Basse \& Müller (2004) (cranidium alone) from the middle Eifelian of the Sauerland, S. magnispina (poorly preserved internal moulds) and $S$. sp. n. L of Basse in Basse \& Müller (2004) (complete specimen) from the Devonian of Morocco. On a preliminary note it is mentioned that $S$. akatastasia has a small thorn on the posterior margin of the palpebral lobe (invest. of priv. coll.) which is not readily visible in the holotype. Feist (1999) did not mention this feature in his material, nor is it visible in Basse's Moroccan specimen or any of the specimens from F-032. 
Family Odontopleuridae Burmeister, 1843

Subfamily Odontopleurinae Burmeister, 1843

\section{Genus Kettneraspis Prantl \& Přibyl, 1949}

Type species. Acidaspis pigra Barrande, 1872.

Discussion. Van Viersen \& Heising (2015) expressed their doubts about the monophyly of Kettneraspis and the exclusive use of the pygidial pleural spine configuration in distinguishing it from the morphologically similar Leonaspis Richter \& Richter, 1917. Under the same conditions we assign Kettneraspis eftychia sp. nov. to this genus here.

\section{Kettneraspis eftychia sp. nov.}

(Figs 19A-D)

v 2012 Kettneraspis cf. bayarti; van Viersen \& Daumeries, p. 10, figs F, G, I.

Etymology. From eftychia (Greek; combination of \&v, good,

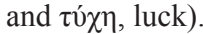

Holotype. IRSNB a13277, internal mould of a complete specimen (IRSNB a13277a; Figs 19B-D) with associated partial external mould (IRSNB a13277b; Fig. 19A).

Type locality and horizon. F-032, Vireux-Molhain; Vieux Moulin Member of the Jemelle Formation.

Diagnosis. Thoracic axial rings bearing two rows of tubercles. Broad (exsag.) thoracic anterior pleural bands bearing a row of large tubercles. Broad, long axial rings. Axial furrows narrow (tr.) and shallow. Anterior axial ring separated by a shallow furrow from broad pseudo-articulating halfring. Postaxial area elevated band-like (exsag.); depressed medially and continued without an interruption onto the posterior border.

Discussion. This species is similar to Kettneraspis elliptica (Burmeister, 1843) from the Ahrdorf Formation in the Eifel and to Kettneraspis bayarti van Viersen, 2007 from the Chavées Member (middle Eifelian part) of the Jemelle Formation in Jemelle. In particular, it shares with $K$. bayarti the anteriorly expanded (tr.) median glabellar lobe which has led to the previous tentative assignment to this species (van Viersen \& Daumeries, 2012). Kettneraspis elliptica is distinguished from the new species by the narrower (tr.) pseudo-articulating half-ring, narrow axial furrows, fewer, larger tubercles on the pygidium, and the presence of a postaxial ridge. Kettneraspis bayarti has a long occipital spine and lacks the row of tubercles on the thoracic anterior pleural bands. Its pygidium is not very well known but can be contrasted by the presence of a postaxial ridge and fewer, smaller tubercles.

\section{Subfamily Koneprusiinae Vaněk \& Pek, 1987}

\section{Genus Koneprusia Prantl \& Přibyl, 1949}

Type species. Acidaspis fuscina Novák, 1890.

\section{Koneprusia sp. A}

(Fig. 19E)

v 2008 Koneprusia sp. A; van Viersen, pp. 85-87, figs 2, 3.

v 2012 Koneprusia sp. A; van Viersen \& Daumeries, p. 10, fig. H, p. 12, unnumb. figs, p. 14.

Material. PLI-02, silicone cast of an articulated incomplete specimen, from F-032, Vireux-Molhain; Vieux Moulin Member of the Jemelle Formation.

Discussion. The occurrence of a representative of Koneprusia at F-032 was first pointed out by van Viersen (2008) who concluded that specimens must have been confused with the slightly more common Kettneraspis specimens that occur in the same locality. One additional Koneprusia specimen was recorded by van Viersen \& Daumeries (2012). The currently available material is insufficient to describe the species fully. Koneprusia has not been found in any of the coeval Belgian localities.

\section{Palaeobiodiversity, palaeobiogeography and events}

\subsection{Characteristics of the trilobite fauna}

In the area of study the Emsian-Eifelian boundary is situated in the Eau Noire Formation (Fig. 20; Bultynck et al., 2000). Corals, brachiopods and crinoids make up a major component of the macrofauna whereas trilobites appear to be poorly diversified. These encompass Acastoides, Basidechenella, Gerastos, Pedinopariops and Tropidocoryphe south of Couvin (van Viersen, 2015). The overlying Vieux Moulin Member of the Jemelle Formation marks the deposition of dark shales and siltstones in the area along with significant changes in the composition of the trilobite fauna. Acastoides and Basidechenella are not known from the Jemelle Formation and went globally extinct at around the Emsian-Eifelian boundary. Gerastos, Tropidocoryphe and Pedinopariops probably continued across the boundary here as they also occur basally in the Jemelle Formation. Additionally, the first occurrences of Asteropyge, Ceratarges, Cyphaspis, Geesops, Diademaproetus, Kettneraspis, Koneprusia, Radiaspis, Scabriscutellum and Septimopeltis are reported (B-079, B-130, F-032). The probably slightly younger B-028 trilobite association,
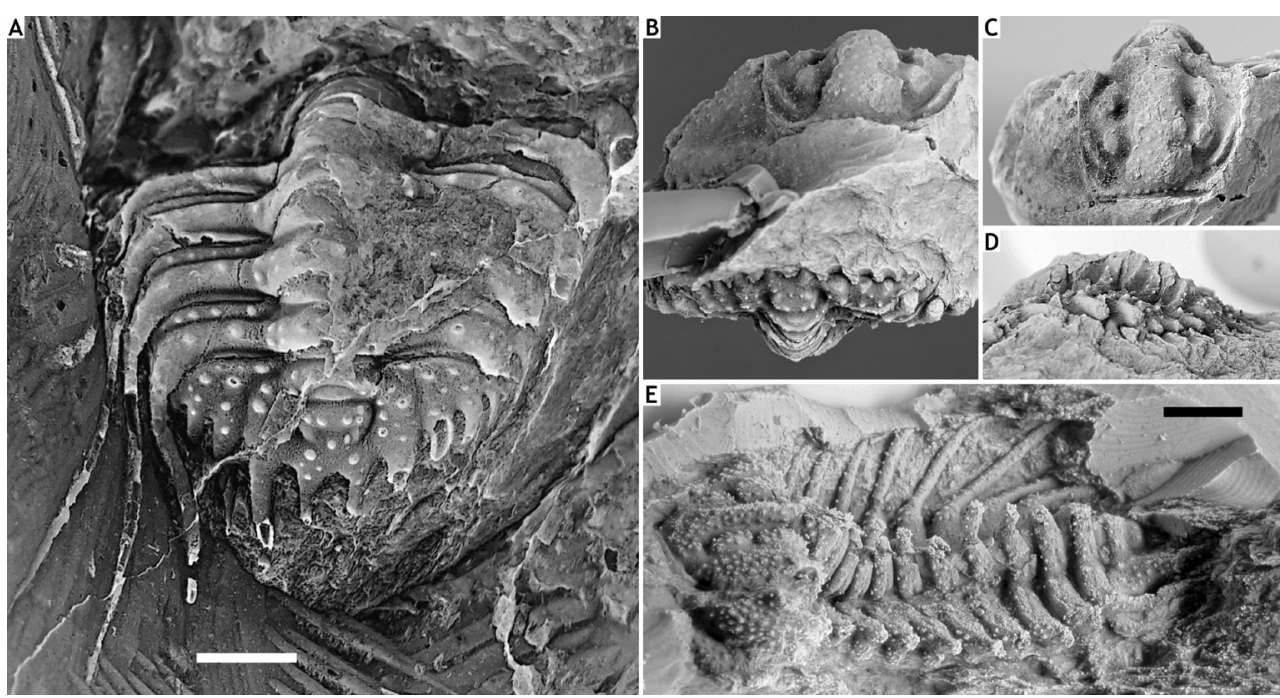

Figure 19. Kettneraspis eftychia sp. nov. from the Vieux Moulin Member of the Jemelle Formation at F-032, Vireux-Molhain.

A. Holotype fragmentary external mould of a complete specimen, IRSNB a13277b, in dorsal view. Digitally inverted image. B-D. Holotype internal mould of a complete specimen, IRSNB a13277a, in anterior (B), dorsal (C) and lateral (D) views.

Koneprusia sp. A from the Vieux Moulin Member of the Jemelle Formation at F-032, VireuxMolhain.

E. Silicone cast of an incomplete specimen, PLI-02, in oblique lateral view.

All scale bars represent $2 \mathrm{~mm}$. 
Ardennes

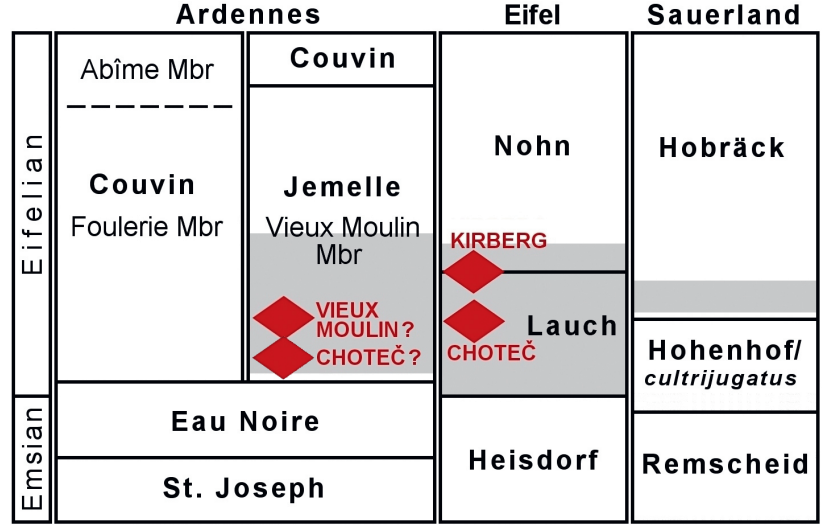

Figure 20. Schematic comparison of the Emsian-Eifelian transition in the Ardennes, Eifel and Sauerland with timing of events indicated. Grey areas are the estimated relative ages of the trilobite faunas from the studied area (B-079, B-130, F-032), Eifel (e.g. Basse, 2006) and Sauerland (e.g. Basse, 2006).

inclusive of dominant Cyphaspis, Dohmiella and Goldius, along with rare Astycoryphe, Ceratarges, Phacops, Scabriscutellum and Tropidocoryphe, is characteristic of the Couvin Formation in the area between Couvin and Nismes. Cyphaspis and Dohmiella range until high in the Couvin Formation east of Nismes (B069) where it overlies the Vieux Moulin Member of the Jemelle Formation (B-130).

Early Eifelian trilobite distribution in southern Belgium is largely facies-controlled. Asteropyge, Diademaproetus, Geesops, Gerastos, Kettneraspis, Pedinopariops, Radiaspis and Septimopeltis are all restricted to siliciclastic deposits of the Jemelle Formation and Astycoryphe, Dohmiella, Goldius and Phacops to the carbonate Couvin Formation. Ceratarges, Cyphaspis, Scabriscutellum and Tropidocoryphe show no preference for an environment. It is remarkable that subsequent to the termination of the Couvin Formation, members of all the aforementioned genera co-occur in miscellaneous associations, in siliciclastic deposits of the overlying Chavées Member (e.g. B-004, B-052). Palaeoenvironment appears to have retained significant control over trilobite distribution in the middle part of the Eifelian although the comparative age of the associations cannot be validated since biostratigraphic control is often lacking. Fluctuations in alpha diversity in the numerous trilobite bearing localities in southern Belgium are indicative of varying local conditions (e.g. van Viersen et al., 2017a). Also, the frequency of occurrences of some taxa may vary considerably (van Viersen \& Prescher, 2010; van Viersen, 2015).

\subsection{Comparisons to other regions}

In the Eifel, the Heisdorf Formation has yielded a fairly rich trilobite fauna partially comparable to that of the Eau Noire Formation, with members of Acastellina, Acastoides, Basidechenella, Coltraneia, Comura, Gerastos, Huginarges, Leonaspis, Scharyia and Treveropyge (e.g. Üxheim 1 locality of Basse \& Müller, 2004; G-099). The overlying (basal Eifelian) calcareous Wolfenbach Member of the Lauch Formation is highly fossiliferous and records the trilobites Acastellina, Asteropyge, Ceratarges, Geesops, Gerastos, Pedinopariops and Sculptoproetus or a closely allied genus (e.g. Basse \& Müller, 2004). The dark, sandy and silty marlstones of the upper Dorsel Member of this formation mark the putative onset of the Chotec Event (Fig. 20; Vodrážková et al., 2013). These beds are generally less rich in fossils, brachiopods excepted. The extinction of Struve's (1982a) "OCA fauna" at the boundary between the Lauch and Nohn formations was named the Kirberg Event (Fig. 20; Struve, 1990; Jansen, 2016). The effects of the Kirberg Event on trilobites remain largely unexplored. This is at least in part due to the fact that there are few published stratigraphically controlled trilobite collections from this interval. However, when comparing the total trilobite diversity of the Lauch and Nohn formations, an increase in the latter may be inferred rather than a reduction. The Nohn Formation has yielded members of Astycoryphe, Ceratarges, Cyphaspis, Dohmiella, Geesops, Gerastos, Goldius, Harpes, Pedinopariops, Phacops, Scabriscutellum, Tropidocoryphe and an undetermined lichid (e.g. Basse, 2006). The trilobite associations of B-079, B-130 and F-032 demonstrate many resemblances to those of the Lauch Formation and basal part of the Nohn Formation in terms of their compositions. Even at the species level the similarities are sometimes compelling. According to van Viersen \& de Wilde (2010) the B-028 association matches best with that of the Kirberg Member of the Nohn Formation based on the occurrences of Astycoryphe, Dohmiella, Goldius and Phacops next to the close similarities between Cyphaspis unguloides (Eifel) and Cyphaspis belgica (B028).

In the western and southern Sauerland, the latest Emsian to earliest Eifelian siltstones and sandstones of the Hohenhof/ cultrijugatus beds (Fig. 20) mark the beginning of an increasingly marine regime in the region. These levels have yielded few identifiable trilobites (e.g. Basse \& Müller, 2004). Locally, the lower part of the overlying Hobräck Formation bears a trilobite association similar to that of the Vieux Moulin Member. Basse \& Müller's (2004) Ebbelinghagen locality in the lower part of the Hobräck Formation has yielded members of Ceratarges, Cornuproetus, Cyphaspis, Geesops, Gerastos, Kettneraspis, Radiaspis, Scabriscutellum, Septimopeltis and Tropidocoryphe.

In the near-shore Asturo-Leonian domain of the Cantabrian Mountains, the Choteč Event was recognised in the sandstones of the Huargas Formation (García-Alcalde et al., 2002). Smeenk (1983) recorded Asteropyge perforata from the base of this unit along with members of Cyphaspis, Diademaproetus, Gerastos, Kettneraspis and Phacopidae.

The changes in the trilobite fauna near the base of the Choteč Limestone (= Choteč Event level) in Bohemia (Chlupáč et al., 1979) are incompatible with the trilobite fauna of the Vieux Moulin Member in terms of the taxa involved: the palaeogeographically widely distributed Kettneraspis is the only genus shared between these units.

In the Armorican Massif the Choteč Event is situated in the Saint Fiacre Formation (Vodrážková et al., 2013) which has yielded a very poorly diversified trilobite fauna. The underlying latest Emsian Bolast Formation, on the other hand, has yielded members of Asteropyge, Ceratarges and Cyphaspis, among other trilobites (Morzadec, 1983).

In the Draa Valley, southern Morocco, Chatterton et al. (2006) described trilobites from the Timrhanrhart Formation at the socalled Zguilma section. These workers distinguished two trilobitebearing levels, ZGEE1 and ZGEE2 of latest Emsian age, near the base of their section. These contain members of Acastoides, Coltraineia, Diademaproetus, Cyphaspis, Erbenochile, Gerastos, Hollardops, Gandlops, Koneprusia, Leonaspis, Wenndorfia, Morocops, Rheiscutellum, Timsaloproetus, Tropidocoryphe and Walliserops. Some $40 \mathrm{~m}$ higher a third level, ZGEE3 of earliest Eifelian age, has yielded the goniatite Pinacites jugleri. Chatterton et al. noticed that the ZGEE3 level contains an impoverished trilobite fauna. Acastoides, Coltraneia, Gerastos, Rheiscutellum and Tropidocoryphe are not known here. Additionally, ZGEE3 introduces but a single new occurrence at the Zguilma section, namely Thysanopeltis. Chatterton et al. (2006) assumed that the Choteč Event occurred somewhere between ZGEE1 and ZGEE3 and that it may have effected the reduced trilobite alpha diversity observed in the latter level. Basse \& Müller (2016) considered ZGEE3 to bear an Emsian rather than an Eifelian trilobite fauna and positioned this level at the very base of the Eifelian. The occurrence of Pinacites jugleri in ZGEE3, however, indicates that it is probably best positioned stratigraphically higher.

\subsection{Early Eifelian Vieux Moulin and Choteč Events}

During the Emsian-Eifelian transition the trilobite fauna in southern Belgium underwent major changes. In the Nismes Vireux-Molhain area the basal dark shales and siltstones of the Vieux Moulin Member have yielded the Vieux Moulin trilobite 
fauna which differs in important aspects from that of the underlying calcareous Eau Noire Formation.

Gouwy \& Bultynck (2003) recognised a shallowing episode in the lower partitus zone in the Ardennes, indicated by the deposition of sandy shales near the base of the Jemelle Formation in the Jemelle area. At the same time the Couvin Formation developed in the Couvin area in what Gouwy \& Bultynck (2003) interpreted as a comparatively shallow water setting followed by an increase in sea water level slightly higher in the partitus and lower costatus zones. It has been argued that this sea level rise could be attributed to the Choteč Event, and that it is responsible for the termination of the first biostromes within the Foulerie Member of the Couvin Formation (Gouwy \& Bultynck, 2003; Denayer et al., 2015). Our localities B-079, B-130 and F-032, basally in the Vieux Moulin Member, are all positioned in proximity of this interval (Figs 2, 20). This is underlined by the occurrence of Pinacites jugleri at B-079 and F-032 which is occasionally associated with the Choteč Event, alternatively called the jugleri Event (Walliser, 1985).

The Choteč Event was recognised in Bohemia where it is characterised by the deposition of blackish shales in neritic settings as part of a major marine transgression (Chlupáč \& Kukal, 1986). This event was anoxic in deeper waters, probably caused by the quickly rising sea level. However, few detailed accounts of the Choteč Event from other regions have been published (Becker \& Aboussalam, 2013). According to Chlupáč (1994) the Choteč Event brought few innovations in trilobite faunas and is chiefly associated with migrations and extinctions instead. Our preliminary data are not entirely inconsistent with that view, in that an exchange of trilobite faunas between southern Avalonia and (peri-)Gondwanan terranes is observed close to a potential Choteč interval (Fig. 21). Asteropyge and Ceratarges, first recorded from the late Emsian in the Armorican Massif, spread to the Ardenno-Rhenish Mountains and Cantabrian Mountains in the early Eifelian. Additionally, Ceratarges appears in the early Eifelian of Morocco and SW England. Diademaproetus, represented in Morocco and the Ardenno-Rhenish Mountains in the late Emsian, spread to the Cantabrian Mountains during the early Eifelian. Cyphaspis, Gerastos, Kettneraspis, Koneprusia, Radiaspis and Tropidocoryphe were cosmopolitan in the Early Devonian. All of these already occurred in the upper Emsian strata of the Ardenno-Rhenish Mountains, arguably effected by the transgressive Daleje Event (van Viersen, 2013, 2015; van Viersen \& Holland, 2016). As such they were omitted from our palaeogeographic maps. Pedinopariops occurs in the upper Emsian of Bohemia and the Ardenno-Rhenish Mountains. It probably persisted in the latter region during the early Eifelian. In the cases of Cyphaspis and Gerastos, there are striking similarities at the species level between congeners from the upper Emsian of Morocco and the lower Eifelian of the ArdennoRhenish Mountains (see chapter Systematic Palaeontology). The potential close affinity of Morocops (Morocco) and Geesops (Ardenno-Rhenish Mountains) has been pointed out previously. The problem with analysing all these occurrences is that stratigraphically controlled data are scarce and relationships with the Choteč Event have not been properly investigated, or not at all. For example, Asteropyge and Ceratarges, which are important components of the B-079 and F-032 associations, first occur in the basal Wolfenbach Member of the Lauch Formation in the Eifel and in the Bolast Formation in the Armorican Massif. These records predate the putative onset of the Choteč Event.

To summarise, the early Eifelian marked the radiation of members of certain trilobite genera along the continental shelves of southern Avalonia and northern Gondwana, but this has yet to be placed in a broader perspective. Additionally, the relationships to the Choteč Event are often unsubstantiated. Similarly, the immigration of exotic taxa in the area of study is noteworthy but cannot be readily linked to the Choteč Event. In order to underline the importance of this marked immigration and to avoid ambiguous use of the Choteč Event here, we provisionally designate this influx 'Vieux Moulin Event' (Fig. 20). The overturn of the Eau Noire trilobite fauna with the termination of key taxa such as Acastoides and Basidechenella is an extinction event not restricted to Belgium that predates the putative position of the Choteč Event here.

\subsection{Middle Eifelian Bakoven and Stony Hollow events}

The shift from the upper part of the Couvin Formation to the overlying Chavées Member of the Jemelle Formation (transition lower-middle Eifelian / costatus-australis zones) in the Couvin area is distinct in that the limestones are terminated and surmounted by shales with limestone intercalations and small bioherms (Bultynck et al., 1991). The trilobite associations in this part of the Chavées Member can be exceedingly rich, both in species and individuals (e.g. B-004, B-052). Asteropyge and Gerastos, which occur in the basal Vieux Moulin Member and are absent in the Couvin Formation, re-appear and phacopids become more abundant and diversified. Dohmiella and Goldius, though ubiquitous, are comparatively rare. Additional "Hercynian" elements (e.g. Austerops, Phaetonellus, Thysanopeltella) not known to occur in older strata in Belgium, are furthermore introduced (van Viersen, 2015; van Viersen et al., 2017a).

These changes, both in lithology and composition of the trilobite fauna, took place in the lower part of the australis zone shortly after the onset of a major transgression (Fig. 2). Denayer et al. (2015) argued that the Bakoven Event should fall within the Chavées Member although they noted the absence of blackish shales in this unit as well as any significant extinctions. DeSantis \&

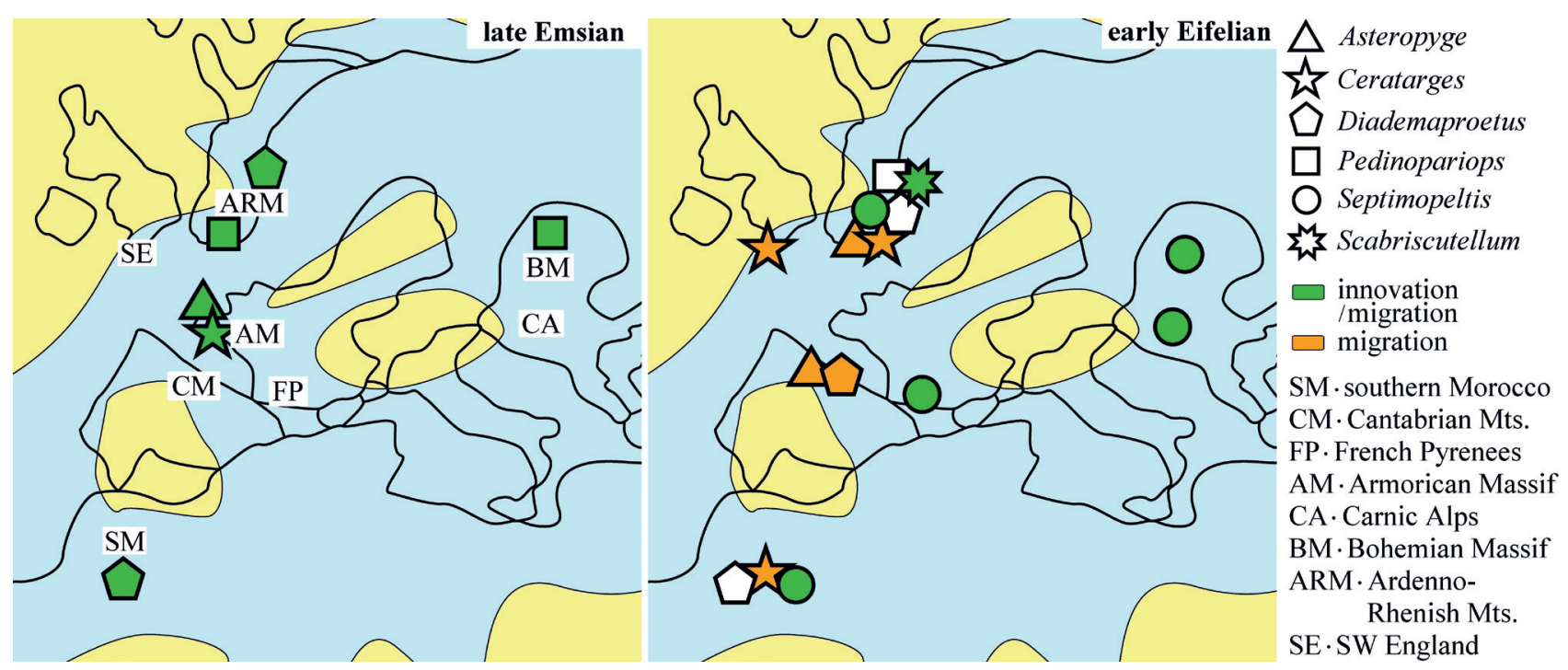

Figure 21. Palaeogeographic maps of southern Avalonia and northern Gondwana during the late Emsian and early Eifelian. Adopted from Scotese (2001) and modified. 
Brett (2011) described the Bakoven Event as an abrupt deepening episode in eastern North America leading to widespread hypoxia and a marked reduction of faunal diversity. These workers reviewed possibly related lithological and faunal changes in western Europe and Morocco. In particular they discussed the occurrence of a richly diversified trilobite association in the Flesten Member of the Ahrdorf Formation (australis zone) which is surmounted by the Niederehe Subformation encompassing sparsely fossiliferous, potentially dysaerobic, dark shales and limestones. This last interval was considered by them to be a putative expression of the Bakoven Event. In the Ardennes, the early middle Eifelian trilobite associations (B-004, B-052) are exceedingly similar to those of the Flesten Member (Gees Subformation in the central Gerolstein Syncline; see van Viersen et al., 2009) and almost certainly of comparable age. This means that the Bakoven Event might be sought in the Ardennes in the upper part of the Chavées Member. Van Viersen \& Vanherle (2018) noticed drastically reduced trilobite diversity near the top of the Chavées Member and in the Lomme Formation where the latter is developed, but attributed this to Struve's "Great Gap", a series of siliciclastic deposits witnessing non-fully marine conditions with a gap in the marine faunal record that culminated at around this time. This part of the Chavées Member is comparable to the upper part of the Junkerberg Formation which surmounts the Ahrdorf Formation in the Eifel and which has yielded a similar, impoverished trilobite fauna (van Viersen et al., 2012). DeSantis \& Brett (2011) described the Junkerberg Formation as a progressively shallower-water environment displaying characteristics of their Stony Hollow Event. The exact sequence of events that led to the reduced trilobite diversity in the Ardennes is not known and requires further study. This leaves the questions of whether or not the Bakoven and Stony Hollow events can be recognised in the Ardennes, and if the Stony Hollow Event might be genetically related to Struve's "Great Gap".

\section{Conclusions}

Contemporary fieldwork at early Eifelian outcrops in the Nismes - Vireux-Molhain area has revealed diversified trilobite associations. Although the sedimentology of our localities has yet to be assessed, changes in lithology and the trilobite faunas between the Eau Noire and Jemelle formations are noteworthy and must be subjected to further study. The term Vieux Moulin Event is used to mark the influx of exotic elements that encompass a large part of the Vieux Moulin trilobite fauna.

Trilobites in the lower Eifelian of the Ardennes are largely facies dependent and their distribution is divided into carbonate and siliciclastic domains. With the termination of the Couvin Formation at the end of the early Eifelian, facies preference was reduced although alpha diversity continued to show fluctuations. More collections under stratigraphic control must be conducted in order to build a database that may support a detailed analysis of trilobite palaeoecology and biostratigraphy in relation to events.

\section{Acknowledgements}

J. De Boeck, I. Kesselaer, D. Lelubre, F. Lerouge, T. Suffeleers, A. Weug, M. Wolvers and the late J. Boel donated some of the studied trilobite specimens. S. Goolaerts participated in helpful discussions on stratigraphy. Review comments provided by M. Basse (Senckenberg Research Institute and Natural History Museum, Frankfurt am Main, Germany) and J. Denayer (University of Liège, Belgium) improved the manuscript. We are grateful to these persons for their support.

\section{References}

Archinal, A., 1994. Zur Morphologie, Systematik, Stratigraphie und Ökologie der Gattung Scutellum (Trilobita; Devon). Senckenbergiana lethaea, 74, 291-324.

Basse, M., 1998. Trilobiten aus mittlerem Devon des Rhenohercynikums: III. Proetida (3), Phacopida (2), Lichida (Lichoidea, Odontopleuroidea) und ergänzende Daten. Palaeontographica (A), 249, 1-162.
Basse, M., 2002. Eifel-Trilobiten 1. Proetida. Goldschneck-Verlag, Korb, $152 \mathrm{p}$.

Basse, M., 2003. Eifel-Trilobiten 2. Phacopida 1. Goldschneck-Verlag, Korb, 198 p.

Basse, M., 2006. Eifel-Trilobiten IV. Proetida (3), Phacopida (3). Quelle \& Meyer-Verlag, Wiebelsheim, 304 p.

Basse, M. \& Müller, P., 2004. Eifel-Trilobiten III. Corynexochida, Proetida (2), Harpetida, Phacopida (2), Lichida. Quelle \& MeyerVerlag, Wiebelsheim, 260 p.

Basse, M. \& Müller, P., 2016. Trilobiten aus dem Ober-Emsium und frühen Eifelium der südlichen Lahnmulde (Rupbach-Schiefer, LeunSchiefer und Ballersbach-Kalk). Abhandlungen der Senckenberg Gesellschaft für Naturforschung, 572, 1-329.

Becker, R.T. \& Aboussalam, Z.S., 2013. The global Choteč Event at Jebel Amelane (western Tafilalt platform) - preliminary data. In Becker, R.T., El Hassani, A. \& Tahiri, A. (eds), International Field Symposium 'The Devonian and Lower Carboniferous of northern Gondwana', Field Guidebook. Documents de l'Institut Scientifique, Rabat, 27, 129-134.

Béthune, P. de, 1954. Carte géologique à l'échelle du 500.000. In Fourmarier, P. (ed.), Prodrome d'une description géologique de la Belgique. Société Géologique de Belgique, Liège.

Bultynck, P., 1970. Révision stratigraphique et paléontologique de la coupe type du Couvinien. Mémoires de l'Institut Géologique de l'Université de Louvain, 26, 1-152.

Bultynck, P. \& Dejonghe, L., 2001. Devonian lithostratigraphic units (Belgium). In Bultynck, P. \& Dejonghe, L. (eds), Guide to a revised lithostratigraphic scale of Belgium. Geologica Belgica, 4, 39-69.

Bultynck, P., Coen-Aubert, M., Dejonghe, L., Godefroid, J., Hance, L., Lacroix, D., Préat, A., Stainier, P., Steemans, P., Streel, M. \& Tourneur, F., 1991. Les formations du Dévonien moyen de la Belgique. Mémoires pour servir à l'explication des Cartes Géologiques et Minières de la Belgique, 30, 1-105.

Bultynck, P., Coen-Aubert, M. \& Godefroid, J., 2000. Summary of the state of correlation in the Devonian of the Ardennes (Belgium - NE France) resulting from the decisions of the SDS. Courier Forschungsinstitut Senckenberg, 225, 91-114.

Chatterton, B.D.E., Fortey, R.A., Brett, K.D., Gibb, S.L. \& McKellar, R.C., 2006. Trilobites from the upper Lower to Middle Devonian Timrhanrhart Formation, Jbel Gara el Zguilma, southern Morocco. Palaeontographica Canadiana, 25, 1-177.

Chlupáč, I., 1994. Devonian trilobites - Evolution and events. Geobios, 27, 487-505. https://doi.org/10.1016/S0016-6995(09)90029-8

Chlupáč, I. \& Kukal, Z., 1986. Reflection of possible global Devonian events in the Barrandian area, C.S.S.R. In Walliser, O.H. (ed.), Global Bio-events: a critical approach. Springer, Berlin, Lecture Notes in Earth Sciences, 8, 169-179.

Chlupáč, I., Lukeš, P. \& Zikmundová, J., 1979. The Lower/Middle Devonian boundary beds in the Barrandian area, Czechoslovakia. Geologica et Palaeontologica, 13, 125-156.

Crônier, C. \& Viersen, A.P. van., 2008. The 'Mur des douaniers', an exceptionally well preserved Early Eifelian fossil site. Bulletin de la Société géologique de France, 179, 89-95.

Denayer, J., Mottequin, B., Marion, J.-M., Devleeschouwer, X. \& Prestianni, C., 2015. The Middle Devonian succession in the Dinant Synclinorium. STRATA, série 1, communications, 17, 3-23.

DeSantis, M.K. \& Brett, C.E., 2011. Late Eifelian (Middle Devonian) biocrises: Timing and signature of the pre-Kačák Bakoven and Stony Hollow Events in eastern North America. Palaeogeography, Palaeoclimatology, Palaeoecology, 304, 113-135. https://doi org/10.1016/j.palaeo.2010.10.013

Dumoulin, V. \& Blockmans, S., 2008. Le passage latéral entre les formations de Couvin et de Jemelle (Eifelien) au bord sud du Synclinorium de Dinant (Belgique) : introduction du Membre de Vieux Moulin - Formation de Jemelle. Geologica Belgica, 11, 25-33.

Feist, R., 1999. First Mid-Devonian trilobites from the Carnic Alps. Abhandlungen der Geologischen Bundesanstalt, 54, 295-302.

García-Alcalde, J.L., Carls, P., Pardo Alonso, M.V., Sanz-López, J., Soto, F., Truyols-Massoni, M. \& Valenzuela-Ríos, J.I., 2002. Devonian. In Gibbons, W. \& Moreno, T. (eds), The Geology of Spain. The Geological Society, London, 67-92.

Godefroid, J., 1968. Contribution à l'étude du Couvinien entre Wellin et Jemelle (Bord sud du bassin de Dinant). Académie royale de Belgique, Classe des sciences, mémoires, deuxième série, 17/3, 1-87.

Gosselet, J., 1884. Compte rendu de la course du 7 septembre, de Vireux à Givet et aux environs de Givet. Bulletin de la Société Géologique de France, 11 (1882-1883), 677-679. 
Gouwy, S. \& Bultynck, P., 2003. Conodont based graphic correlation of the Middle Devonian formations of the Ardenne (Belgium): implications for stratigraphy and construction of a regional composite. Revista Española de Micropaleontología, 35, 315-344.

Jansen, U., 2016. Brachiopod faunas, facies and biostratigraphy of the Pridolian to lower Eifelian succession in the Rhenish Massif (Rheinisches Schiefergebirge, Germany). In Becker, R.T., Königshof, P. \& Brett, C.E. (eds), Devonian Climate, Sea Level and Evolutionary Events. Geological Society, London, Special Publications, 423, 45122. https://doi.org/10.1144/SP423.11

Kowalski, H., 1990. Trilobiten aus dem Devon der Eifel. Aufschluss, Sonderband, 33, 11-63.

Lecompte, M., 1962. Faciès et stratigraphie dans le Dévonien inférieur et moyen de la Belgique. In Erben, H.K. (ed.), 2. Internationale Arbeitstagung über die Silur/Devon-Grenze und die Stratigraphie von Silur und Devon, Bonn-Bruxelles 1960, Symposiums-Band. E. Schweizerbart'sche Verlagsbuchhandlung, Stuttgart, 143-150.

Lecompte, M., 1970. Die Riffe im Devon der Ardennen und ihre Bildungsbedingungen. Geologica et Palaeontologica, 4, 25-71.

Lütke, F., 1990. Contributions to a phylogenetical classification of the subfamily Proetinae Salter, 1864 (Trilobita). Senckenbergiana lethaea, 71, 1-83.

Magrean, B., 2006. Revision of some Devonian trilobites from Belgium. The genera Astycoryphe, Tropidocoryphe, Eifliarges and Koneprusia. Bulletin de l'Institut royal des Sciences naturelles de Belgique, Sciences de la Terre, 76, 67-77.

Magrean, B., 2007. A revision of Devonian trilobites from Belgium. - Part 2. The genera Gerastos and Cornuproetus. Bulletin de 1'Institut royal des Sciences naturelles de Belgique, Sciences de la Terre, 77, 31-40.

Magrean, B. \& Taghon, P., 2013. Trilobiten aus dem Mitteldevon der Ardennen. Teil 3: Scutelliden und Harpiden. Fossilien, 2013, 74-77.

Maillieux, E., 1904. Quelques mots sur les trilobites du Couvinien des environs de Couvin. Bulletin de la Société belge de Géologie, de Paléontologie et d'Hydrologie, 17, 579-582.

Maillieux, E., 1907a. Compte rendu de 1'excursion dans les environs de Couvin les 14 et 15 août 1906 de la Société belge de Géologie, de Paléontologie et d'Hydrologie. Bulletin de la Société belge de Géologie, de Paléontologie et d'Hydrologie, 21, Mémoires, 133-167.

Maillieux, E., 1907b. Sur deux pygidiums aberrants du "Bronteus flabellifer" Goldf. Bulletin de la Société belge de Géologie, de Paléontologie et d'Hydrologie, 21, Procès-verbaux, 255-257.

Maillieux, E., 1919. Remarques sur la faune trilobitique de l'assise des schistes et calcaires à Calceola sandalina du bord sud du Bassin de Dinant. Bulletin de la Société belge de Géologie, de Paléontologie et d'Hydrologie, 29, 52-55.

Maillieux, E., 1933. Terrains, roches et fossiles de la Belgique. Musée royal d'Histoire naturelle de Belgique, Brussels, 217 p.

Maillieux, E., 1938. Le Couvinien de l'Ardenne et ses faunes. Mémoires du Musée royal d'Histoire naturelle de Belgique, 83, 1-57.

Morzadec, P., 1983. Trilobites du Dévonien (Emsien-Famennien) de la rade de Brest (Massif Armoricain). Palaeontographica (A), 181, 103-184.

Přibyl, A. \& Vaněk, J., 1971. Studie über die Familie Scutelluidae Richter \& Richter (Trilobita) und ihre phylogenetische Entwicklung. Acta Universitatis Carolinae, Geologica, 4, 361-394.

Richter, R., 1914. Das Übergreifen der pelagischen Trilobitengattungen Tropidocoryphe und Thysanopeltis in das normale Rheinische Mitteldevon der Eifel (und Belgiens). Centralblatt für Mineralogie, Geologie und Paläontologie, 1914, 85-96.

Richter, R. \& Richter, E., 1956. Grundlagen für die Beurteilung und Einteilung der Scutelluidae (Tril.). Senckenbergiana lethaea, 37, 79-124.

Schraut, G., 2000. Eine neue Unterart von Phacops (Phacops) sparsinodosus Struve 1970 aus dem Mittel-Devon von Marokko. Senckenbergiana lethaea, 80, 525-535.

Scotese, C.R., 2001. Atlas of Earth History, Volume 1, Paleogeography. PALEOMAP Project, Arlington, Texas, $52 \mathrm{p}$.

Smeenk, Z., 1983. Devonian trilobites of the southern Cantabrian Mountains (northern Spain) with a systematic description of the Asteropyginae. Leidse Geologische Mededelingen, 52, 383-511.

Struve, W., 1982a. The Eifelian within the Devonian frame, history, boundaries, definitions. In Ziegler, W. \& Werner, R. (eds), On Devonian Stratigraphy and Palaeontology of the Ardenno-Rhenish Mountains and Related Devonian Matters. Courier Forschungsinstitut Senckenberg, 55, 401-432.

Struve, W., 1982b. Beiträge zur Kenntnis der Phacopina (Trilobita), 10: Neue Untersuchungen über Geesops (Phacopinae; Unter- und MittelDevon). Senckenbergiana lethaea, 63, 473-495.
Struve, W., 1985. Beiträge zur Kenntnis der Phacopina (Trilobita), 13: Phacops sartenaeri aus dem Eifelium der Ardennen, Belgien. Senckenbergiana lethaea, 65, 465-469.

Struve, W., 1990. Paläozoologie III (1986-1990). In Ziegler, W. (ed.), Wissenschaftlicher Jahresbericht 1988/89 des Forschungsinstituts Senckenberg, Frankfurt am Main. Courier Forschungsinstitut Senckenberg, 127, 251-279.

Taghon, P., Bonino, E. \& Mottequin, B., 2012. A new representative of the lichid genus Ohleum (Trilobita) from the Eifelian (Middle Devonian) of southern Belgium. Geologica Belgica, 15, 120-125.

Viersen, A.P. van, 2006a. New Middle Devonian trilobites from VireuxMolhain (Ardennes, northern France). Senckenbergiana lethaea, 86, 63-75. https://doi.org/10.1007/BF03043635

Viersen, A.P. van, 2006b. Dohmiella Lütke 1990 (Trilobita) a valid proetid genus, with two new species from Belgium and Germany. Senckenbergiana lethaea, 86, 229-241. https://doi.org/10.1007/ BF03043490

Viersen, A.P. van, 2008. First record of the odontopleurid trilobite Koneprusia from the lower Eifelian of Vireux-Molhain (northern France), with remarks on the associated trilobite fauna. Geologica Belgica, 11, 83-91.

Viersen, A.P. van, 2013. Latest Early to early Middle Devonian acastid trilobites from the eastern part of the Dinant Synclinorium, Belgium (Rhenohercynian Zone). Memoirs of the Association of Australasian Palaeontologists, 44, 1-10.

Viersen, A.P. van, 2015. Trilobites du Dévonien des Ardennes (zone rhéno-hercynienne): biostratigraphie, évolution et événements. Fossiles, Revue française de Paléontologie, 11, 5-24.

Viersen, A.P. van \& Daumeries, G., 2012. Les trilobites du Dévonien ardennais du "Mur des douaniers" à Vireux-Molhain. Fossiles, Revue française de Paléontologie, 8, 5-15.

Viersen, A.P. van \& Heising, H., 2015. Description of Kettneraspis? prescheri sp. nov. (Trilobita, Odontopleuridae) from the "couche rouge" (Pragian, Lower Devonian) in Morocco. Geologica Belgica, 18, 15-20.

Viersen, A.P. van \& Holland, D., 2016. Morphological trends and new species of Cyphaspis (Trilobita, Otarioninae) in the Devonian of Morocco, Turkey, Germany and Belgium. Geologica Belgica, 19, 251-271. http://dx.doi.org/10.20341/gb.2016.008

Viersen, A.P. van \& Prescher, H., 2007. Note on Cyphaspis Burmeister 1843 (Trilobita, Aulacopleuridae), with a review of several species mainly from the Devonian of Belgium and Germany. Senckenbergiana lethaea, 87, 157-170. https://doi.org/10.1007/BF03043912

Viersen, A.P. van \& Prescher, H., 2008. Devonian Proetidae (Trilobita) from the Ardennes Massif (Belgium, N France) and the Eifel Hills (W Germany). In Steurbaut, E., Jagt, J.W.M. \& Jagt-Yazykova, E.A. (eds), Annie V. Dhondt Memorial Volume. Bulletin de 1'Institut royal des Sciences naturelles de Belgique, Sciences de la Terre, 78, 9-29.

Viersen, A.P. van \& Prescher, H., 2010. Taxonomy and biostratigraphy of some proetid trilobites in the Middle Devonian of the Ardennes and Eifel (Rhenohercynian Zone). Bulletin de l'Institut royal des Sciences naturelles de Belgique, Sciences de la Terre, 80, 5-45.

Viersen, A.P. van \& Vanherle, W., 2018. The rise and fall of Late Devonian (Frasnian) trilobites from Belgium: taxonomy, biostratigraphy and events. Geologica Belgica, 21, 73-94. https://doi.org/10.20341/ gb.2018.005

Viersen, A.P. van \& Wilde, B. de, 2010. Goldius angusticalix sp. nov. (Trilobita, Scutelluidae) from the Couvin Formation (Middle Devonian) in Belgium, with a preliminary list of scutelluid species from the Ardennes. Geologica Belgica, 13, 153-162.

Viersen, A.P. van, Prescher, H. \& Savelsbergh, J., 2009. Description of two new trilobites from the Ahrdorf Formation (Middle Devonian) at the "Trilobitenfelder" of Gees, Eifel, Rhenish Mountains. Bulletin de l'Institut royal des Sciences naturelles de Belgique, Sciences de la Terre, 79, 43-53.

Viersen, A.P. van, Rossum, A. van \& Prescher, H., 2012. New data on Astycoryphe, Dohmiella, Longiproetus and Quadratoproetus (Trilobita, Proetidae) from the Middle Devonian in the Ardennes, Belgium. Neues Jahrbuch für Geologie und Paläontologie, Abhandlungen, 264, 77-87. https://doi.org/10.1127/00777749/2012/0233

Viersen, A.P. van, Taghon, P. \& Magrean, B., 2017a. The phacopid trilobites Austerops McKellar \& Chatterton, 2009, Hottonops gen. nov. and Loreleiops gen. nov. from the Devonian of the ArdennoRhenish Mountains. Neues Jahrbuch für Geologie und Paläontologie, Abhandlungen, 283, 53-68. https://doi.org/10.1127/njgpa/2017/0626 
Viersen, A.P. van, Holland, D. \& Koppka, J., 2017b. The phacopine trilobite genera Morocops Basse, 2006 and Adrisiops gen. nov. from the Devonian of Morocco. Bulletin of Geosciences, 92, 13-30. https://doi.org/10.3140/bull.geosci.1610

Vodrážková, S., Frýda, J., Suttner, T.J., Koptíková, L. \& Tonarová, P., 2013. Environmental changes close to the Lower-Middle Devonian boundary; the Basal Choteč Event in the Prague Basin (Czech Republic). Facies, 59, 425-449. https://doi.org/10.1007/s10347-0120300-x

Walliser, O.H., 1985. Natural boundaries and Commission boundaries in the Devonian. Courier Forschungsinstitut Senckenberg, 75, 401-408.

Whittington, H.B. \& Kelly, S.R.A., 1997. Morphological terms applied to Trilobita. In Kaesler, R.L. (ed.), Treatise on invertebrate paleontology, Part O, Arthropoda 1. Trilobita, revised. Volume 1: Introduction, Order Agnostida, Order Redlichiida. Geological Society of America, Boulder, Colorado and University of Kansas Press, Lawrence, Kansas, 313-329. 